Portland State University

PDXScholar

Summer 9-3-2014

\title{
Community Connections: Exploring the Constructive Potential of Facebook for Civic Engagement
}

Sarah Ruth Martin

Portland State University

Follow this and additional works at: https://pdxscholar.library.pdx.edu/open_access_etds

Part of the Social Influence and Political Communication Commons, and the Social Media Commons Let us know how access to this document benefits you.

\section{Recommended Citation}

Martin, Sarah Ruth, "Community Connections: Exploring the Constructive Potential of Facebook for Civic Engagement" (2014). Dissertations and Theses. Paper 1987.

https://doi.org/10.15760/etd.1986

This Thesis is brought to you for free and open access. It has been accepted for inclusion in Dissertations and Theses by an authorized administrator of PDXScholar. Please contact us if we can make this document more accessible: pdxscholar@pdx.edu. 


\title{
Community Connections:
}

Exploring the Constructive Potential of Facebook for Civic Engagement

by

Sarah Ruth Martin

A thesis submitted in partial fulfillment of the requirements for the degree of

\author{
Master of Science \\ in \\ Communication
}

\author{
Thesis Committee: \\ Lauren Frank, Chair \\ Kevin Kecskes \\ Lee Shaker
}

Portland State University

2014 
(C) 2014 Sarah Ruth Martin 


\begin{abstract}
Recognizing the importance of civic engagement to the health of local communities and the overall success of a democracy, this research sought to better understand the relationship between online media use and civic engagement. Specifically, the constructive potential of the social networking site Facebook was explored using the theoretical framework of communication infrastructure theory (CIT; Ball-Rokeach, Kim, \& Matei, 2001). Results of a cross-sectional survey with a national sample of 375 participants indicated that Facebook does hold potential for civic engagement. The two most important findings of the research were that Facebook facilitated connection to neighborhood storytelling and that connection to storytelling was positively associated with civic engagement. As such, results indicated that Facebook holds potential for civic engagement insofar as the site facilitates connection to neighborhood storytelling. Additionally, Facebook was a regular part of participants' daily routines, a means to maintain social capital, and a forum for occasional civic participation. Cumulatively, these results highlight a number of strengths that citizens and communities can build upon to improve social capital and increase civic engagement.
\end{abstract}




\section{DEDICATION}

For Evan, my trusty sounding board and proof reader.

Thank you for your unwavering support. 


\section{ACKNOWLEDGMENTS}

I would especially like to thank my advisor, Dr. Lauren Frank. You have been a wonderful mentor and I am so grateful for your enthusiasm, encouragement, guidance, and helpful feedback. I would also like to thank Dr. Lee Shaker and Dr. Kevin Kecskes for serving as committee members. I appreciate your willingness to commit your time and energy to providing thoughtful feedback and constructive criticism. Additionally, I would like to thank the Department of Communication for investing in this research by providing funding assistance for data collection.

A special thanks to my family and friends. Jenna, thank you for being a great thesis buddy - it was reassuring to tackle this project with a kindred spirit and celebrate milestones together. Mom and Dad, I cannot thank you enough for all the opportunities you have provided me and your constant support and encouragement. Evan, thank you for patiently enduring the moments of stress, providing comedic relief, and constantly devising new ways to be supportive. 


\section{TABLE OF CONTENTS}

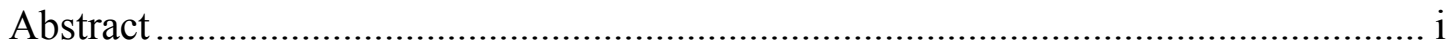

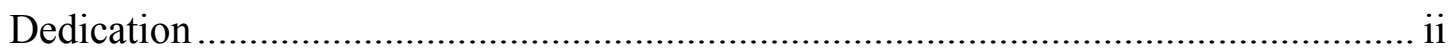

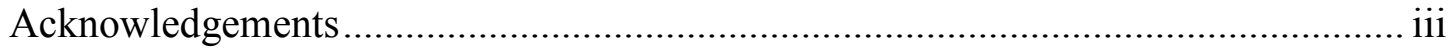

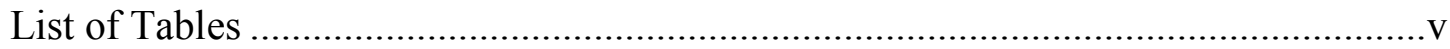

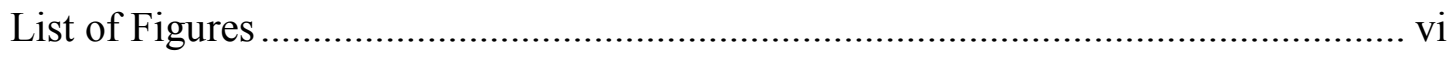

Chapter 1

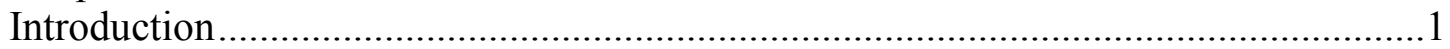

Chapter 2

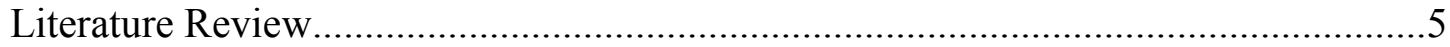

Chapter 3

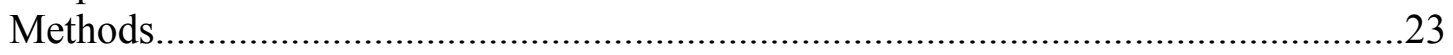

Chapter 4

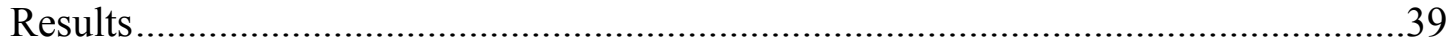

Chapter 5

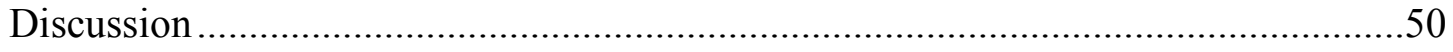

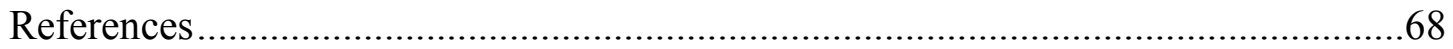

Appendices

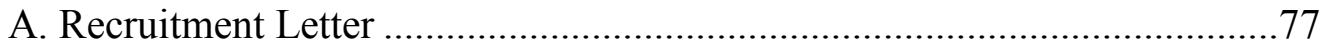

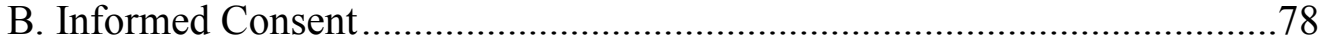

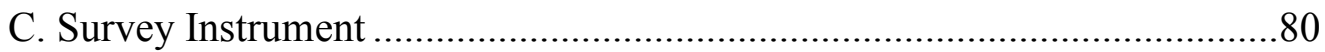




\section{LIST OF TABLES}

Table 1

Descriptive Statistics for Facebook Use Measures

Table 2

Connection to Micro-Level Storytelling on Facebook

Table 3

Connection to Meso-Level Storytelling on Facebook

Table 4

Civic Participation .44

Table 5

Spearman's rho Correlations, Means, and Standard Deviations of Civic Engagement.

Table 6

OLS Regressions Predicting Neighborhood Belonging, Collective

Efficacy, and Civic Participation....

Table 7

OLS Regression Predicting ICSN on Facebook 


\section{LIST OF FIGURES}

Figure 1

Box and arrow model of Hypothesis 2, Hypothesis 3,

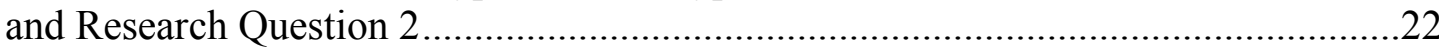




\section{CHAPTER 1: INTRODUCTION}

Civic engagement has long been regarded an important feature of American democracy. After visiting the United States during the early nineteenth century, Alexis de Tocqueville (1845/2010) marveled at Americans' propensity to participate in voluntary associations. He observed that these associations were essential to ensure the health of the overall democracy and to garner the support and collaboration necessary to accomplish goals in every realm of life. Since de Tocqueville's initial musings on Americans' remarkable propensity to engage collectively in associations, many have argued that these associations are essential to the functioning and success of American democracy (e.g., Delli Carpini, 2000; Putnam, 1995, 2000; Verba, Brady, \& Schlozman, 1995).

Because of its importance to the vitality of American democracy as well as the health and functioning of our local communities, discussions of how best to foster engagement and what constitutes engagement garner significant attention and are often characterized by conflicting perspectives. As social media have become more pervasive, conflicting perspectives about their ability to facilitate engagement and participation have become increasingly salient. Some celebrate the potential that comes along with the "unprecedented levels of production and distribution of ideas, public deliberation, and network organization" on social networking sites (Bennett, 2008, p. 1) while others caution that online involvement may be better characterized as "slacktivism" than activism (Morozov, 2009). 
Excitement about the potential of social media is evident in news coverage of demonstrations and uprisings across the globe and in assessments of recent political campaigns. From the Arab Spring demonstrations across Northern Africa and the Middle East and the Norwegian Rose Marches in 2011 to the Gezi Park protests in Turkey and the Euromaidan demonstrations in Ukraine in 2013, news coverage has emphasized and celebrated the use of Facebook and Twitter to spread information and promote insurgent agendas. The innovative use of new media in Barack Obama's 2008 Presidential Campaign has also been celebrated. The campaign's use of new media has been credited with extending the reach of the campaign and enabling new modes of involvement ranging from simple actions such as sharing a page or post to more invested forms of involvement such as developing and sharing content or coordinating events and fundraisers (Abroms \& Lefebvre, 2009).

Others approach the potential of social media for engagement and active participation with caution and skepticism. In a 2010 article for The New Yorker, Malcolm Gladwell criticized "outsized enthusiasm for social media” (para. 9) and rejected the idea that the tools of social media have "reinvented social activism" (para. 7). Concerned that we may have lost sight of what true activism looks like in the midst of preoccupation with social media, he identified two crucial distinctions between traditional activism and online activism. First, he argued that high-stakes traditional activism is built on strong social ties while online activism is characterized by weak ties. Second, he argued that the non-hierarchical structure of online networks lacks the rules, procedures, and centralized authority required to for a sustainable movement. After 
articulating these two distinctions, Gladwell argued that online activism may be harmful because it diverts time and energy away from organizations promoting strategic, disciplined activity and conditions people to expend minimal effort for engagement.

There is undoubtedly truth in both perspectives of this debate about the potential of social networking sites for encouraging civic engagement. Online engagement provides access to information, people, and tools for organization which can be important precursors to volunteering, raising awareness, educating others, and starting new organizations in the offline world (Raynes-Goldie \& Walker, 2008). At the same time, however, many forms of online engagement fall short of the high-stakes activism needed to effect lasting social change. In light of the reality that social networking sites are increasingly central to the ways that people choose to engage (Bennett, 2008), a measured approach acknowledging the value in both perspectives is needed to assess the affordances and limitations of social networking sites for civic engagement. In particular, it is important for communication scholars to engage in the types of scholarship that encourage service and engagement (Brammer \& Parker, 2007).

The overarching goal of this study was to adopt such a measured approach to assess the constructive potential of Facebook for civic engagement. As will be discussed in Chapter 2, much of the communication research exploring the relationship between various media and civic engagement is descriptive and lacks a cohesive explanatory and predictive theoretical framework. Therefore, this study complements and extends existing research on the topic by employing the theoretical framework of communication infrastructure theory (CIT; Ball-Rokeach, Kim, \& Matei, 2001). Chapter 3 provides a 
detailed discussion of the method that was employed, and Chapter 4 presents the statistical results of the hypothesis testing. Finally, the discussion presented in Chapter 5 situates the relevance of the results to existing theory and proposes real-world applications.

The results of this study indicate that an essential aspect of Facebook's potential for civic engagement is its ability to facilitate connection to neighborhood storytelling. Connection to neighborhood storytelling was positively associated with civic engagement among this sample. These findings, along with descriptive data about participants' Facebook use, provide important insight into how citizens and communities might capitalize on the strengths of social networking sites like Facebook to improve social capital and increase civic engagement. 


\section{CHAPTER 2: LITERATURE REVIEW}

Generally defined, civic engagement is the "coming together of interested groups and citizens to discuss and address issues of concern" (Coleman, Lieber, Mendelson, Kurpius, 2008, p. 181). While individual definitions of civic engagement align with this general conceptualization, there is little consensus across research about the specific activities that constitute civic engagement. Definitions vary in the extent, variety, and formality of activities that are representative of civic engagement (Adler \& Goggin, 2005). Overall, civic engagement has been conceptualized to include individual and collective activities ranging from conventional forms of political participation such as voting, participating in a demonstration, or signing a petition to community-oriented activities such as involvement with a community organization or neighborhood association and volunteer work (Bennett, 2008). The activities associated with civic engagement are distinctive because they produce benefits that extend beyond the individuals who are directly involved in the activity. Furthermore, the activities associated with civic engagement enable citizens to build the necessary skills to efficiently collaborate and pursue common goals (Scheufele \& Shah, 2000). This common purpose "plays a central role in the health and function of democratic societies by channeling collective action toward community building” (Shah, Cho, Eveland, \& Kwak, 2005, p. 533).

The importance of civic engagement to a functioning democracy and healthy local communities has prompted research programs across the fields of sociology, political science, education, and communication. While there is common interest in civic 
engagement, disagreement regarding the types of activities that are representative of civic engagement has resulted in conflicting assessments of the current state of civic engagement. Some scholars adopt a narrow definition of civic engagement as consisting of traditional forms of political participation or formal membership in official organizations. Those who adopt this definition argue that civic engagement has significantly declined since the 1960 s because survey data indicates that membership in formal clubs and organizations has declined and Americans are less involved in traditional aspects of public life such as voting, consuming news, and knowledge of politics and political processes (Delli Carpini, 2000; Putnam, 2000). Others argue that such data do not indicate a decline in civic engagement, but a restructuring. As traditional indicators of civic engagement have declined, there has been an increase in volunteerism and consumer politics (Bennett, 2008). According to this line of research, when civic engagement is more broadly defined to encompass these new forms of participation, civic engagement has actually increased rather than decreased (Verba et al., 1995; Wells, 2010).

Adopting the perspective of overall decline, Robert Putnam (2000) attracted the attention of communication scholars by identifying television as the culprit responsible for lower levels of political participation, civic engagement, and social capital. In his time displacement hypothesis, he argued that time spent watching television takes away from time that could be spent engaging with the community. This charge prompted a considerable amount of communication research investigating the relationship between uses of various media and civic engagement. While some studies adopt and extend 
Putnam's (2000) time displacement hypothesis and others challenge it, a considerable portion of previous research is dedicated to either defending or condemning various media. The current study moves beyond this divisive discourse to explore the constructive potential of social networking sites for civic engagement. After first articulating the basis of civic engagement in social capital theory and reviewing past research on media use and civic engagement, a brief overview of the theoretical framework for communication infrastructure theory (CIT) is provided and the research questions and hypotheses are presented.

\section{Civic Engagement \& Social Capital}

Civic engagement and social capital are often described as interdependent concepts. Social capital theory draws from sociological perspectives about social norms and economic theory to explain the value of social networks (Coleman, 1990). The central idea of social capital is that an individual's social connections-family, friends, neighbors, and associates - are an important asset that can be "called on in a crisis, enjoyed for its own sake, and leveraged for material gain” (Woolcock \& Narayan, 2000, p. 226).

Social capital varies across at least four dimensions (Putnam \& Goss, 2002). First, social capital may arise from and produce formal or informal social relations. Second, it may vary in strength by both resulting from and producing strong or tenuous social ties. Third, social capital may also be characterized as bridging or bonding. Bridging is the bringing together of disparate groups. In contrast, bonding involves strengthening ties between similar people and groups who already share a social 
relationship. Finally, social capital may vary insofar as it promotes individual gain or public good. Social capital is rarely characterized by either pole of any of these four dimensions. Rather, the social capital of a relationship is usually best characterized somewhere along a continuum of each of the four dimensions. Although theorists agree that social capital varies along these dimensions, theorists differ distinctly in whether they conceptualize the advantages of social capital primarily in terms of the individual or emphasize collective benefits.

Bourdieu (1986) and Burt (2005) discussed social capital in terms of individual advantages and as a strategic resource that can be leveraged for personal gain. Bourdieu (1986) conceived of social capital as a scarce resource within a class-driven structure. He described it as an individual resource that is generated through group membership and social associations. Individuals with "investments" in lasting networks of formal and informal relationships are at an advantage because group membership provides access to the resources of other group members. Burt (2005) also conceptualized social capital in terms of individual advantage. He defined social capital as "the advantage created by a person's location in a structure of relationships" (Burt, 2005, p. 4). According to Burt, (2005) some individuals are more successful because they are better positioned within their social networks to notice the need for and to facilitate strategic connections between unconnected social networks. His concepts of brokerage (strategically connecting individuals from different social networks) and closure (fostering trust to minimize risks associated with new connections) emphasize leveraging one's interpersonal connections for personal gain. According to the conceptualizations of social capital provided by 
Bourdieu (1986) and Burt (2005), the collective benefits that are often associated with social capital are an incidental by-product of individuals' pursuit of personal gain.

Coleman (1990) and Putnam (1995) placed greater emphasis on the collective benefits that arise from social capital. Rather than conceiving of it as a scarce resource to be leveraged primarily for individual gain, Coleman (1990) regarded social capital as an attribute of the social structure within which an individual is embedded. Because an individual cannot create a social structure that is conducive to social capital, the benefits of social capital cannot be the personal property of an individual. Instead, the benefits of social capital are advantageous to everyone who is part of the social structure. Putnam followed Coleman's conceptualization and explored social capital as both an individualand community-level resource that is a feature of the social structure. Putnam (1995) defined social capital as "features of social organization such as networks, norms, and social trust that facilitate coordination and cooperation for mutual benefit" (p. 67). From this perspective, individual- and community-level advantages of social capital are attained through collective problem solving.

Within the conceptualization of social capital emphasizing social trust, coordination, and cooperation, many researchers focus on civic engagement as a feature, individual-level indicator, or outcome of social capital. Civic engagement offers a real and meaningful opportunity for members of a community to provide input and get involved in the process of discussing and finding solutions to issues of public concern (Bimber, 1999; Coleman et al., 2008; Shah, McLeod, \& Yoon 2001). This collective and cooperative action is dependent on norms of reciprocity and social trust included in 
Putnam's definition of social capital. Thus, civic engagement depends on the social capital of individual and network relations for collective action, and the collective action involved in civic engagement reinforces and generates new social connections which strengthen social capital (Rohe, 2004). For this reason, social capital and civic engagement can be understood as recursive features in a reinforcing relationship.

\section{Social Capital, Civic Engagement, \& Media Use}

Demographic \& dispositional variables. Some communication research focuses on demographic and dispositional variables to explore the relationship between media use and civic engagement. This vein of research has examined the role of social mechanisms such as demographics, frequency and characteristics of interpersonal discussion about politics and civic matters, and psychosocial characteristics such as personality traits. Research focused on demographic variables has found that individuals who are white, well-established in their communities, older, more educated, and have higher incomes tend to have higher levels of social capital and be more engaged in their local communities (Beaudoin, 2009; Beaudoin \& Thorson, 2006; Matei \& Ball-Rokeach, 2003). Additionally, the more often that individuals talk with others about the information that they read, see, or hear in the media, the more likely they are to have higher levels of civic engagement (Hardy \& Scheufele, 2005; Jeffres, Lee, Neuendorf, \& Atkin, 2007; Scheufele, 2002; Zhang \& Seltzer, 2010). Finally, personality traits such as openness, extroversion, opinion leadership, and self-confidence are also significant in describing the relationship between media use and social capital (Kim, Hsu, and Gil de Zuniga, 2013; Scheufele \& Shah, 2000). 
Taken together, these results may indicate that media use is most likely to improve social capital and increase civic engagement among individuals who are already well connected and engaged. Although these studies demonstrate that media use may reinforce existing social capital and levels of civic engagement (Norris, 2001), they do not clarify whether media holds constructive potential. These studies do not provide sufficient insight into whether media can be used to create social capital and increase civic engagement for a broader range of people.

Uses and gratifications. Another significant portion of communication research investigating the relationship between media use and civic engagement is couched in the uses and gratifications tradition. Rather than focusing on a simple measure of time spent with media as Putnam (2000) did when he proffered his time displacement hypothesis, communication scholars examine the associations between particular uses of media and civic engagement. The rationale behind this approach is that media effects differ based on the specific needs that an individual seeks to gratify through media use (Rubin, 1993).

Research focusing on specific uses of media has found that using media to gain or share information is consistently associated with higher levels of civic engagement while using media for entertainment is not. Shah, Cho, Eveland, and Kwak (2005) found that reading hard news in newspapers and on the internet to gain information was associated with higher levels of political discussion and civic engagement. Moy, Manosevitch, Stamm, and Dunsmore (2003) found that using the internet for information searches, correspondence, visiting a political site, contacting a representative, and communitybased activities was positively associated with civic engagement. In contrast, Scheufele 
and Nisbet (2002) found that individuals who frequently use the internet for entertainment purposes knew fewer relevant current event facts and felt less efficacious about their role in the democratic process. The results of these studies refine Putnam's time displacement hypothesis by demonstrating that time spent with media does not always displace civic activities. Using media for socially-oriented purposes or to gather and disseminate political and community information actually complements and augments civic engagement.

Differences by medium. Another major line of research has focused on the relationship between the use of specific media and civic engagement. Conclusions of these studies vary due to different operationalizations of media use. However, generally, the findings indicate that newspaper readership is more strongly associated with civic engagement and participation than television viewing (Bakker \& de Vreese, 2011; Beaudoin, 2009; McLeod, Scheufele, \& Moy, 1999), and internet use is positively related to civic engagement (Bakker \& de Vreese, 2011; Boulianne, 2009; Jennings \& Zeitner, 2003; Moy et al., 2005; Shah et al., 2005).

Most recently, researchers have focused on the relationship between social networking sites and social capital. Social networking sites are web-based services with three primary attributes: (1) they allow users to develop public or semi-public profiles, (2) the sites list other users with whom an individual shares a connection, and (3) the sites enable users to view their connections' profiles (boyd \& Ellison, 2007). Recent research indicates that social networking sites have positive potential for civic engagement. For example, Pasek, more, and Romer (2009) found that online social networking was 
strongly associated with offline civic engagement. Likewise, Gil de Zuniga, Jung, and Valenzuela (2012) found that seeking information via social networking sites was a positive and significant predictor of people's social capital and civic and political participation, both online and offline. Kim, Hsu, and Gil de Zuniga (2013) also found that individuals who use social networking sites such as Facebook and Twitter had more diverse discussion networks and higher levels of civic participation.

Brady, Verba, and Schlozman's (1995) resource model of political participation provides a possible explanation for these positive relationships found in recent research. The resource model describes the ways in which individuals' possession of free time, money, and civic skills help to explain differing levels of political participation and why particular people engage in specific political activities. Specifically, their discussion of the ways in which individuals develop civic skills may help to explain social media sites' facilitative potential for civic engagement. They argue that individuals' communication and organizational capacities are honed outside of political contexts. The workplace, voluntary associations, and churches provide opportunities to develop and practice civic skills that can later be channeled toward political participation. It may be that that social media sites provide another context to develop and practice these important communication and organizational skills.

While each of these areas of research—personal traits, specific media uses, and effects of specific media - has contributed to an understanding of the relationship between media use and civic engagement, the resulting picture is incomplete. These studies do clarify elements of the relationship between media use and civic engagement, 
but the research and findings are not situated within a cohesive predictive or explanatory theoretical framework. The resulting understanding is, therefore, context-specific and holds little potential for efforts to use media constructively to increase social capital and encourage civic engagement. As such, there is a need to situate research investigating the relationship between media and civic engagement within a predictive theoretical framework. Communication infrastructure theory provides such a framework.

\section{Communication Infrastructure Theory}

Communication infrastructure theory (CIT) offers a description and explanation for how neighborhoods are constructed through communication (Matei \& Ball-Rokeach, 2003). CIT operates on the fundamental assumption that communication is central to the process of belonging and focuses on neighborhoods as the primary communication environments where belonging thrives or withers. The theoretical model advanced by CIT accounts for multi-level communicative processes and structural variables that have the potential to facilitate or constrain communication. The two primary elements of the communication infrastructure proposed by CIT are the neighborhood storytelling network and the communication action context (Ball-Rokeach, Kim, \& Matei, 2001).

The neighborhood storytelling network is a web of residents, organizations, and media who tell stories about the community (Matei \& Ball-Rokeach, 2003). Neighborhood storytelling may take many forms (e.g., positive or negative, formal or informal, oral or written, etc.). The only criterion is that stories are about the local community. This is an essential feature of neighborhood storytelling because it is through discourse about the local community that individuals construct a collective 
identity for the community and begin to feel like they belong by thinking of themselves as residents of that community (Ball-Rokeach et al., 2001). The storytelling network is a multi-level system that consists of both interpersonal and mediated storytelling with macro-, meso-, and micro-level storytellers. The storytelling levels are differentiated both in terms of their referents and imagined audiences. Macro-level storytellers (e.g., mainstream media) tell stories with whole cities, regions, nations, or the world as their referent and an imagined audience as broad as an entire city, county, or region. Mesolevel storytellers are media or organizations that focus on particular parts of a city or segments of the population as their referents and imagined audiences. Micro-level storytellers are networks of neighbors and residents who tell stories about the neighborhood or community (Ball-Rokeach et al., 2001).

The communication action context (CAC) is the setting in which the storytelling network operates. The term was borrowed from Habermas (1984) to capture the idea that structural and socio-cultural aspects of a neighborhood or community can either constrain or enable interaction and therefore affect the development and strength of neighborhood storytelling networks (Matei \& Ball-Rokeach, 2003). The CAC varies by degree of openness. The openness of a CAC is influenced by factors such as neighborhood safety, the presence of gathering places, and the quality of local services (Wilkin, Moran, BallRokeach, Gonzalez, \& Kim, 2010). An open CAC encourages communication and facilitates neighborhood storytelling while a closed context discourages encounters and constrains communication. Rather than being fully open or fully closed, every CAC has elements of both openness and closedness (Ball-Rokeach et al., 2001). 
The ideal communication infrastructure consists of a highly integrated neighborhood storytelling network and a highly open communication action context. Effective communication infrastructures have storytelling systems with many stories to share with a range of referents (Ball-Rokeach et al., 2001). It is not necessary that the stories told in these networks focus solely on commonalities or contribute to a single master narrative. Instead, the most important feature of a strong storytelling network is that the stories at each level maintain and strengthen the connection between the levels (Ball-Rokeach et al., 2001).

From a CIT perspective, connection to a strong communication infrastructure with an open CAC and a highly integrated storytelling network produces a sense of neighborhood belonging. Belonging is conceptualized as a subjective and objective attachment to a neighborhood manifested through the activities that neighbors engage in together and how neighbors feel about each other (Ball-Rokeach et al., 2001). Within the multi-level neighborhood storytelling network, micro- and meso-level storytelling are particularly important in fostering neighborhood belonging because storytelling at these levels focuses on the local community more consistently (Ball-Rokeach et al., 2001). Communities with strong connections to an integrated storytelling network have higher levels of neighborhood belonging (Ball-Rokeach et al., 2001).

The theoretical model of belonging posited by CIT draws on and extends literature describing the roles of local media in community (Ball-Rokeach et al., 2001). Stamm's (1985) dynamic model of newspapers as an integrating mechanism posits a cyclical and recursive relationship between community ties and newspaper use. CIT 
extends this dynamic model of newspaper use and community ties to local television and cable channels, local radio, and community organizations. According to CIT, connection to these meso-level storytellers both generates and is a result of feelings of neighborhood belonging. CIT also incorporates structural variable such as residential tenure, homeownership, and socioeconomic characteristics that have been linked to personal identification with a neighborhood and affective ties to a place (Jeffres, 2002). Residential tenure and home ownership are of particular relevance for CIT because they have been consistently related to belonging and it is assumed that the "longer people have lived in an area, the more opportunity they have had to develop the inclination and resources to engage in storytelling generally and in storytelling neighborhood in particular" (Ball-Rokeach et al., 2001).

Communication infrastructure theory \& civic engagement. CIT has been extended to provide a theory-driven approach to examining the potential of a communication infrastructure to foster belonging, construct community, and enable collective action (Kim \& Ball-Rokeach, 2006a). Kim and Ball-Rokeach (2006a) outlined three interrelated features of civic engagement: neighborhood belonging, collective efficacy, and civic participation. Within CIT, these three features of civic engagement are predicated upon connection to an integrated storytelling network within a conducive communication action context. Through neighborhood storytelling, residents develop a collective identity with shared desires and lived experiences. These shared desires and experiences produce a sense of neighborhood belonging that is the foundation for common goals and collective action. Collective efficacy refers to residents' trust that 
their neighbors will join together to solve community problems. Civic participation refers to the actual investment of time or money that residents contribute to the problemsolving process. CIT holds that connections to a neighborhood storytelling network are critical to enabling residents to actually participate. CIT theorizes that civic engagement both depends on a functioning communication infrastructure and strengthens the existing structure. Thus, storytelling is central to civic engagement.

CIT provides a cohesive, predictive, and explanatory theoretical model for the role of communication and media in civic engagement. An important area for the development of this model is examining the role of social media in communities' communication infrastructures. Meso-level storytellers are essential to a well-integrated communication infrastructure because they are the bridge between micro-level and macro-level storytellers (Ball-Rokeach et al., 2001). Local news media, one form of traditional meso-level linkages, have declined in recent years. Specifically, newspapers are cutting coverage of state capitals, city halls, and local events as they reduce staff to stay financially viable (Kirchhoff, 2011), fewer broadcast television stations produce original news programming (Goldfarb, 2011), and consolidation of radio station ownership to national organizations has also led to a decline in local news coverage (Huntemann, 1999). As these traditional media face financial challenges and consolidation, the local news that they do produce is more general and often shared between news outlets (Goldfarb, 2011; Kirchhoff, 2011). Consequently, these traditional media are providing less news about and for local areas, making them weaker meso-level storytellers. 
As local coverage declines in traditional print, television, and radio news media, alternative meso-level linkages are likely to be increasingly important for an integrated storytelling network. Matei and Ball-Rokeach (2003) identified the internet as a weak meso-linkage that bridges gaps between storytelling levels and contributes to belonging. Since their 2003 publication, internet use has become much more common, and social networking sites have become increasingly popular. According to an annual report on American journalism released by the Pew Research Center, social media are an increasingly important source for learning about news events. According to the 2013 report, $15 \%$ of respondents say that the most common way they hear about news events is from family and friends through social networking sites (Enda \& Mitchell, 2013). While these results may indicate that social networking sites hold tremendous potential as a link in an integrated storytelling network, another study conducted by Pew found that very little of that potential was used (Pew Research Journalism Project, 2010). A comprehensive examination of the news ecosystem in Baltimore, MD indicated that the primary functions of social media were to break stories and facilitate distribution, while most of what the public learned was driven by traditional media (Pew Research Journalism Project, 2010).

These changes to the communication landscape highlight the importance of examining how social networking sites fit into the communication infrastructure. This study will focus specifically on the most popular social networking site, Facebook. A recent report from the Pew Research Center identified Facebook as the most popular social networking site among adult internet users. With $67 \%$ of adult internet users using 
Facebook, the site is more than four times as popular as the next most used site, Twitter, at 16\% (Duggan \& Brenner, 2013). The rising importance of social networking sites and the popularity of Facebook specifically prompt the following research question:

RQ1: How do participants use Facebook?

The following hypotheses focus on micro- and meso-level storytelling because the CIT model of civic engagement identifies connection to these levels of storytelling as the most essential for civic engagement (Kim \& Ball-Rokeach, 2006b). As a highly interactive and popular communication medium, Facebook is expected to facilitate participants' connections to the communication infrastructure. As online media become more ubiquitous and fully integrated into our daily lives it is difficult for people to recall after the fact whether the source of information was offline or online (Bimber, 2000). Because of this blurred distinction between online and offline sources, the following twopart hypothesis is proposed:

H1a: Scope of connection to overall micro-level storytelling will be positively associated with scope of connection to micro-level storytelling on Facebook.

H1b: Scope of connection to overall meso-level storytelling will be positively associated with scope of connection to meso-level storytelling on Facebook.

The CIT model of civic engagement identifies neighborhood belonging, collective efficacy, and civic participation as three interrelated features of civic engagement (Kim \& Ball-Rokeach, 2006a). The model also identifies integrated connection to a storytelling network as essential to the development of these features of civic engagement. As such, based on the CIT model of civic engagement, the following hypotheses are proposed: 
$\mathrm{H} 2$ : Feelings of neighborhood belonging, collective efficacy, and civic participation will be positively associated with each other.

H3: Integrated connection to a storytelling network on Facebook will be positively associated with (a) feelings of neighborhood belonging, (b) collective efficacy, and (c) civic participation.

\section{Enjoyment}

Examining how well residents enjoy the process of connecting to their neighborhood storytelling network may provide new insight into how CIT theorizes communication infrastructures work. The convenience and ease of making and maintaining connections on Facebook may contribute to higher levels of enjoyment of the process of staying connected to an integrated storytelling network. Past research from a uses and gratifications perspective has focused on a variety of media uses ranging from information gathering to relaxation. However, there has been very little focus on the potential explanatory value of enjoyment in the relationship between media use and civic engagement. Coleman, Lieber, Mendelson, and Kurpius (2008) tested the relationship between enjoyment of a civic website and civic engagement. Results indicated that websites that are designed for maximum usability and with an appealing appearance are associated with higher levels of both enjoyment and civic engagement. Nash and Hoffman (2009) found that enjoyment plays a role in the acquisition of political knowledge. Higher levels of enjoyment of the process of keeping up with the news were associated with higher political knowledge. Political knowledge is a variable that is often studied in relation to civic engagement with higher levels of political knowledge 
consistently associated with higher levels of civic and political engagement (Scheufele, 2002). Both of these studies indicate that enjoyment of the information gathering process is associated with positive outcomes. Not only is enjoyment an under examined variable overall, it also has never been examined from a CIT perspective. Thus, the following research question is proposed:

RQ2: Does enjoyment of using social networking sites moderate the relationship between integrated connection to the storytelling network on Facebook and (a) feelings of neighborhood belonging, (b) collective efficacy, and (c) civic participation?

These research questions and hypotheses were examined using a cross-sectional survey, and the details of the method are discussed in Chapter 3.

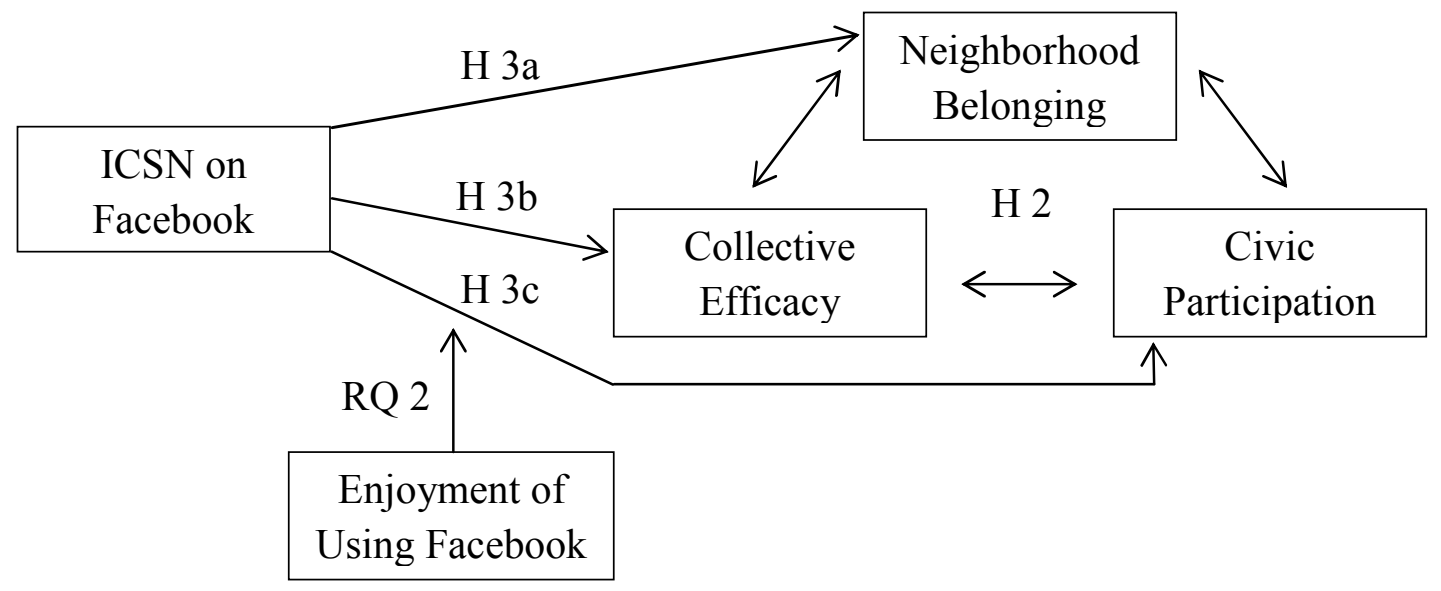

Figure 1. Box and arrow model of Hypothesis 2, Hypothesis 3, and Research Question 2. 


\section{CHAPTER 3: METHODS}

The overarching goal of this study was to explore the constructive potential of social networking sites to facilitate civic engagement. In addition to this overarching goal, this research aimed to accomplish two secondary goals. The first was to contribute to communication research on civic engagement by situating the study within the explanatory and predictive framework of CIT. And the second was to extend past research on both civic engagement and CIT by exploring the role of enjoyment in the relationship between using social networking sites and civic engagement.

Williams and Monge (2001) argue that there are three instances when quantitative research methods are appropriate:

(1) when measurement can offer a useful description of whatever you are studying, (2) when you may wish to make certain descriptive generalizations about the measures, and (3) when you wish to calculate probabilities that certain generalizations are beyond simple, chance occurrences. (p. 5)

Based on these guidelines, a quantitative research method was an appropriate means to accomplish the goals of this study because it allowed for descriptive generalizations based on the data that was collected and also enabled hypothesis testing based on the CIT model of civic engagement. Furthermore, a quantitative methodology allowed for statistical examination of the role of enjoyment in the relationship between civic engagement and integrated connection to a storytelling network on Facebook.

\section{Study Design and Instrument}

This study employed a cross-sectional survey design to examine the relationship between civic engagement, connection to a storytelling network, and enjoyment of using Facebook. A cross-sectional survey design provided insight into the relationship between 
these variables at a particular point in time (Babbie, 2007). Although this method did not provide insight into larger trends or possible causal relationships between variables, the resulting data did provide a useful preliminary snapshot that can be extended in future research.

The survey instrument was divided into four primary sections. The first section was an informed consent describing the general goal of the study, explaining that participation was voluntary, assuring participants' confidentiality and anonymity, describing the risks associated with participation, and providing contact information for the primary investigator (see informed consent in Appendix B). The next section consisted of two questions asking participants if they had a Facebook account and whether they had actively used their account at least three times during the past week. Participants who did not meet these inclusion criteria were automatically directed to the end of the survey. Participants who answered in the affirmative were asked nine items measuring intensity of Facebook use, 31 items measuring uses and gratifications of Facebook, three items measuring enjoyment of using Facebook, four items measuring the extent to which participants use Facebook for news, and 22 items measuring scope of connection to storytelling on Facebook. The third section consisted of items borrowed from past CIT research measuring belonging, collective efficacy, civic participation, and scope of overall connection to storytelling. The final section of the survey consisted of nine demographic questions. The full questionnaire is included in Appendix C. 


\section{Data Collection}

The population for this study was all adults over the age of 18 who lived in the United States and had a Facebook account. The unit of analysis was individuals, and the goal sample size for the study was 400 participants. A power analysis based on Matei and Ball-Rokeach's (2003) measurement of scope of connection to micro-level storytelling $(M=4.6, S D=2.9)$ and belonging $(M=20.0, S D=6.5)$ indicated that a sample of 400 participants would have enough statistical power $(0.80)$ to detect a difference as small as 0.32 when the significance level for a two-tailed test was set at $\alpha=$ .05. The power analysis was performed using an online calculator provided by Harvard (Schoenfeld, 2010).

After obtaining approval from the institutional review board (IRB) at Portland State University, data collection took place between January 24, 2014 and January 26, 2014. Participants were recruited through a convenience sampling technique by placing an advertisement on Mechanical Turk, a service provided by amazon.com. The advertisement invited anyone who was at least 18 years of age, currently lived in the United States, had a Facebook account, and had actively used that account at least three times during the past week to participate in a study about how people feel about and get involved with their local communities. Individuals who followed this advertisement saw the recruitment letter describing the general purpose of the study, criteria for participation, possible risks associated with participation, rights of research participants, assurances of confidentiality, procedure for participation, and information about compensation. The letter also provided contact information for the primary investigator 
and for the office of Research and Strategic Partnerships at Portland State University (see recruitment letter in Appendix A). Participants were compensated $\$ 0.50$ for their participation. This compensation was chosen because it was commensurate with compensation offered for other surveys similar in length and complexity on Mechanical Turk.

Individuals who opted to participate followed a link to the survey hosted in Qualtrics online survey software. On average, the survey took approximately 8 minutes to complete and participants' responses were automatically recorded by Qualtrics. The final page of the survey thanked participants for their participation and provided a randomly-generated completion code along with instructions to enter the code into Mechanical Turk to receive compensation for their participation. The compensation was handled entirely by Mechanical Turk. Mechanical Turk did not have access to survey responses nor did the researcher have access to participants' personal information, ensuring participants' anonymity.

\section{Data Cleaning}

Of the 449 individuals who followed the link provided in the Mechanical Turk recruitment advertisement, 404 participants met the inclusion criteria. Responses from these 404 participants were inspected for quality. First, participants who fell one standard deviation below the mean completion time and participants who fell three standard deviations above the mean completion time were eliminated. The resulting range of completion times was between 3.71 minutes and 21.20 minutes $(M=7.88, S D=$ 3.18). Second, participants' responses were inspected for evidence of response set. 
Third, responses to the text-entry questions inquiring about participants' total number of Facebook friends and number of Facebook friends in their local community were inspected for inconsistencies. Participants who reported more local Facebook friends than total Facebook friends were eliminated. The data cleaning process eliminated 29 participants, resulting in a sample of 375 participants. Subsequent descriptive and inferential statistics are based on this sample of 375 participants.

\section{Participants}

Participants ranged in age from 18 to 79 years old $(M=32.8, S D=11.5)$ and $52.0 \%$ of the sample was male. Most participants identified as White/Caucasian (79.2\%), 8.5\% identified as African American, 6.4\% identified as Asian, and 4.3\% identified as Hispanic. The sample skewed urban as $38.9 \%$ described the area where they lived as a city, $34.2 \%$ as a suburb of a city, $13.6 \%$ as a town, and $12.8 \%$ as a rural area. Participants' length of residence in their local communities ranged from less than a year to 48 years with a sample average of 7.6 years $(S D=8.5)$. Almost half of the sample owned their home (45.1\%) and the median combined annual household income for the sample was $\$ 40,000$ to $\$ 49,999$.

\section{Measures}

Facebook intensity. Intensity of Facebook use was measured with eight items borrowed from Ellison, Steinfield, and Lampe (2007). Six attitudinal items measured the extent of participants' emotional connection to Facebook on a five-point Likert scale $(1=$ Strongly disagree, 5 = Strongly agree). Likert items included: "Facebook is part of my everyday activity," "I am proud to tell people I'm on Facebook," "Facebook has become 
part of my daily routine," "I feel out of touch when I haven't logged onto Facebook for a while," "I feel I am part of the Facebook community," and "I would be sorry if Facebook shut down." The extent of participants' active engagement with Facebook was measured with an opened ended question about their total number of Facebook friends and a Likerttype item about the average amount of time spent on Facebook per day during the past week $(1=0-14 \text { minutes, } 2=15-29 \text { minutes, } 3=30-59 \text { minutes, and } 4=1 \text { hour or more })^{1}$. The total number of Facebook friends was transformed by taking the log and then the mean of the eight intensity items was computed $(M=3.25, S D=0.73, \alpha=.86)$.

Participants were also asked a single item about the number of their Facebook friends who lived in their local community $(M=100, S D=145)$.

Enjoyment of using Facebook. Enjoyment of using Facebook was measured with a three-item scale borrowed from Lin and $\mathrm{Lu}$ (2011). Participants were asked to respond on a five-point Likert scale $(1=$ Strongly disagree, $5=$ Strongly agree $)$ to the statements "using Facebook provides me with a lot of enjoyment," "I have fun using Facebook," and "using Facebook bores me." After reverse coding "using Facebook bores me," participants' responses to the enjoyment items were averaged $(M=3.58, S D=0.89$, $\alpha=.88)$

Facebook use for news. The extent to which participants used Facebook for news was measured with a four-item scale adapted from Gil de Zuniga, Jung, and Valenzuela's (2012) social networking site use for news scale. Participants were asked to indicate on a ten-point Likert-type scale $(1=$ Never, $10=$ All the time $)$ how often they

\footnotetext{
${ }^{1}$ Average amount of time spent on Facebook per day differed from measures used in past research insofar as the range was from 1 to 4 instead of from 1 to 5 .
} 
used Facebook to "stay informed about current events and public affairs," "stay informed about the local community," "get news about current events from news media," and "get news about current events through friends." Responses to these four items were averaged $(M=5.97, S D=2.30, \alpha=.87)$.

Uses and gratifications of Facebook. Participants' uses and gratifications of Facebook were measured with a 30-item scale adapted from Smock, Ellison, Lampe, and Wohn (2011). The scale measured nine dimensions of motivation for using Facebook: relaxing entertainment, expressive information sharing, escapism, cool and new trend, companionship, professional advancement, social interaction, habitual pass time, and to meet new people. Items shared the common prompt "I use Facebook..." and were measured on a Likert scale ranging from 1 (Strongly disagree) to 5 (Strongly agree). Items were randomized within the survey instrument. Responses to items measuring each dimension were averaged to yield nine mean scores describing participants' uses and gratifications for Facebook.

The relaxing entertainment dimension was measured with five items $(M=3.43$, $S D=0.85, \alpha=.89$ ). Examples of of relaxing entertainment items include "Because it's enjoyable," "Because it's entertaining," and "Because it relaxes me." The expressive information sharing dimension was measured with five items such as "To provide information," "To present information about a special interest of mine," and "To tell others a little bit about myself' $(M=3.22, S D=0.83, \alpha=.81)$. Escapism was measured with three items $(M=2.82, S D=0.94, \alpha=.73)$. Items included "So I can forget about school, work, or other things," "So I can get away from the rest of my family or others," 
and "So I can get away from what I'm doing." The cool new trend dimension was measured with three items such as "Because everybody else is doing it" $(M=2.84, S D=$ 0.94, $\alpha=.75$ ). Companionship was also measured with three items (e.g., "So I won't have to be alone") $(M=2.80, S D=1.04, \alpha=.82)$. Professional advancement was measured with three items asking about using Facebook to network with professional contacts and share a resume or work sample $(M=2.32, S D=0.96, \alpha=.78)$. Social interaction was measured with three items asking about the use of Facebook to keep in touch with friends and family. This dimension of the scale was adapted by adding one item, "To communicate with friends who live nearby" $(M=4.07, S D=0.68, \alpha=.63)$. Habitual pastime was measured with five items such as "Because I just like to play around on Facebook" and "When I have nothing better to do" $(M=3.62, S D=0.77, \alpha=$ .81). The final dimension was measured with a single item, "To meet new people" $(M=$ $2.51, S D=1.21)$

Overall scope of connection to micro-level storytelling. Overall scope of connection to micro-level storytelling was measured in the typical way for CIT research by asking participants "How often do you have discussions with other people about things happening in your neighborhood?” (Ball-Rokeach, Kim, \& Matei, 2001). Participants responded on a ten-point Likert-type scale $(1=$ Never, $10=$ All the time; $M=$ $4.44, S D=2.40)$

Scope of connection to micro-level storytelling on Facebook. Scope of connection to micro-level storytelling on Facebook was measured with five items developed for this study. Items asked participants how often they engaged in 
communicative acts on Facebook that contribute to discussions about things happening in their neighborhoods. The communicative acts that were measured included writing status updates and timeline posts, reading status updates, commenting on status updates, and “liking” friends' status updates. All five items were measured on a ten-point Likert-type scale $(1=$ Never, $10=$ All the time $)$. Responses to the five items were averaged ${ }^{2}(M=$ 5.61, $S D=2.17, \alpha=.89)$.

Overall scope of connection to meso-level storytelling. The procedure for measuring scope of connection to meso-level storytelling was borrowed from BallRokeach et al. (2001). The measure consisted of two dimensions: connection to community organizations and connection to local media. The two dimensions were measured independently and then summed to produce a score ranging from 0 to 8 that represented overall scope of connection to meso-level storytelling $(M=3.67, S D=2.04)$. The details for measuring connection to community organizations and connection to local media follow.

Connection to community organizations. Connection to community organizations was measured by asking participants if they belonged to five different types of organizations (sport or recreational; cultural, ethnic, or religious; neighborhood or homeowner; political or educational; and other). Membership was coded as 1, and responses were summed to produce a score ranging from 0 to $5(M=1.74, S D=1.48)$. Past research (e.g., Ball-Rokeach et al., 2001) has found that some participants do not

\footnotetext{
${ }^{2}$ Scope of connection to micro-level storytelling on Facebook was computed by averaging participants' responses to the five items rather than summing responses so that overall connection to micro-level storytelling and connection to micro-level storytelling on Facebook would have the same theoretical range of 1 to 10 .
} 
report membership in a religious organization even when they regularly attend religious services. Following Ball-Rokeach et al. (2001), an additional question was asked about church attendance. Participants who reported attending religious services more often than once every few weeks but did not indicate membership in a religious organization were credited 1 point.

Connection to local media. Participants' connection to local media was measured with three items asking approximately how many hours they spent during the past week "reading newspapers produced for your area or for your ethnic group" $(M=$ $2.14, S D=1.15)$, "watching television and cable channels that target your area or are produced for your ethnic group" $(M=2.72, S D=1.66)$, and "listening to radio stations that target your area or are produced for your ethnic group" $(M=2.42, S D=1.20$; BallRokeach et al., 2001). Time spent with each medium was measured on a seven-point scale $(0=$ None, $6=5$ hours or more $)$. Data was collapsed into a dichotomous measure such that any amount of time spent with a medium was coded as 1 and no time spent with a medium was coded as $0^{3}$. Responses to the three items were then summed to produce a score (range $=0$ to 3 ) representing the breadth of participants' connection to local media $(M=1.93, S D=1.11)$.

\section{Scope of connection to meso-level storytelling on Facebook. Scope of}

connection to meso-level storytelling on Facebook involved a similar multi-step process.

\footnotetext{
${ }^{3}$ Responses to the connection to local media items were collapsed into a dichotomous measure because this is the typical practice for CIT research (Ball-Rokeach et al., 2001; Kim \& Ball-Rokeach, 2006b).

Statistical analyses for Hypothesis $1 \mathrm{~b}$ and the post hoc analysis investigating the relationship between overall ICSN and ICSN on Facebook were also run without dichotomizing participants' responses to the connection to local media items. Adjusting the method for computing connection to local media did not impact the strength or significance of the Pearson's $r$ correlations for these analyses.
} 
Again, connection to community organizations and local media was measured independently and the scores from each measurement were summed. The score for scope of connection to meso-level storytelling on Facebook ranged from 0 to $11(M=3.83, S D$ $=2.78)$.

Connection to community organizations on Facebook. To measure connection to community organizations on Facebook, the measure from Ball-Rokeach et al. (2001) was prefaced with a description of possible ways of connecting with community organizations on Facebook (e.g. joining a Facebook group or "liking" a Facebook page). After this description, participants were asked if they were connected to any of five types of community groups or organizations on Facebook (sport or recreational; cultural, ethnic, or religious; neighborhood or homeowner; political or educational; and other). Following the method borrowed from past CIT research, connections were coded as 1 and responses were summed to yield a score ranging from 0 to $5(M=1.98, S D=1.44)$.

Connection to local media on Facebook. Connection to local media on Facebook was measured by adapting the measure for overall connection to local media (Ball-Rokeach et al., 2001). Participants were asked to think about their activities on Facebook during the past week and indicate whether $(0=N o, 1=Y e s)$ they read any stories from newspapers produced for their area or ethnic group, watched any video clips from television and cable channels produced for their area or ethnic group, and listened to sound clips from radio stations that target their local area $(M=1.22, S D=1.12)$. Participants were also asked three questions about whether they shared content from any 
of these media on Facebook $(M=0.64, S D=1.00)$. Responses were summed to produce a score ranging from 0 to $6(M=1.85, S D=1.87)$.

Integrated connection to a storytelling network on Facebook. Integrated connection to a storytelling network (ICSN) represents the extent to which connections to micro- and meso-level storytelling are integrated into individuals' daily lives (Kim \& Ball-Rokeach, 2006b). The method for computing the variable was borrowed from Kim and Ball-Rokeach (2006b). Before calculating ICSN on Facebook, z-scores were computed for scope of connection to micro-level storytelling on Facebook, scope of connection to local media on Facebook, and scope of connection to community organizations on Facebook. These standardized scores were recoded to a range of 1 (lowest $20 \%$ of scores) to 5 (highest $20 \%$ of scores). After these conversions, the interaction between the variables was calculated with the equation ICSN = $\sqrt{L C \times I N S}+\sqrt{I N S \times O C}+\sqrt{O C+L C}$, which produced a variable with a theoretical range of 3 to 15 . In this equation, LC represents the z-score for connection to local media on Facebook, INS represents the z-score for scope of connection to micro-level storytelling on Facebook, and OC represents the z-score for connection to community organizations on Facebook $(M=8.41, S D=3.37)$.

Civic engagement. This research borrowed CIT's conceptualization of civic engagement as consisting of collective efficacy, civic participation, and neighborhood belonging (Kim \& Ball-Rokeach, 2006a). As such, each of these three features of civic engagement was measured independently. 
Collective efficacy. Collective efficacy is "residents' trust in their community's capacity to mobilize neighborhood problem-solving activities” (Kim \& Ball-Rokeach, 2006a, p. 188). This variable was measured in the typical way for CIT research with a six-item scale asking participants how many neighbors they felt they could count on to do something if "a stop sign or speed bump was needed to prevent people from driving too fast through your neighborhood," "there were dangerous potholes on the street where you live," "the sports field that neighborhood kids want to play on has become unsafe due to poor maintenance or gangs," "you ask them to help you organize a holiday block party," "a child in your neighborhood is showing clear evidence of being in trouble, or getting into big trouble," and "the trees along the streets in your neighborhood are uprooting the sidewalks making them unsafe" $(1=$ None, $5=A l l)$. Responses were averaged to yield a collective efficacy score with higher scores indicating higher levels of collective efficacy $(M=2.47, S D=0.94, \alpha=.92)$.

Civic participation. Civic participation was measured with seven items adapted from Kim and Ball-Rokeach's (2006b) five-item scale. The first three items ("Since moving to your current neighborhood have you attended a city council meeting, public hearing, or neighborhood council meeting," "since moving to your current neighborhood have you written a letter to the editor of a newspaper, television station, or magazine," and "since moving to your current neighborhood have you contacted an elected official about a problem") were borrowed directly from the existing scale. The remaining two items ("since moving to your current neighborhood have you circulated a petition?" and "since moving to your current neighborhood have you taken part in any political 
demonstration or protest?") were expanded to ask about participation both offline and on Facebook. Response options for these questions were dichotomous $(0=N o, 1=Y e s)$. Responses were summed to produce a score ranging from 0 to 7 with higher scores indicating greater breadth of participation $(M=0.96, S D=1.49, \alpha=.74)^{4}$.

Neighborhood belonging. Neighborhood belonging was measured with an eightitem belonging index (Ball-Rokeach et al., 2001). Four items measured participants' feelings about and attachment to their neighbors (e.g., "You are interested in knowing what your neighbors are like" and "You enjoy meeting and talking to your neighbors") on a five-point Likert scale $(1=$ Strongly disagree, $5=$ Strongly agree $)$. The remaining four items measured everyday exchange behavior between participants' and their neighbors (e.g., "How many of your neighbors do you know well enough to ask them to keep watch on your house or apartment?" and "How many of your neighbors do you know well enough to ask them for a ride?") on a six-point scale $(0=$ None, $5=5$ or more $)$.

Responses to these eight items were summed to yield an overall belonging score ranging from 5 to $40(M=17.32, S D=7.21, \alpha=.87)$.

Demographics. Standard demographic items asking about gender, age, and race were measured with one item each. Past research has also found statistically significant differences in civic engagement according to the type of community (i.e., urban vs. rural), income level, level of education, residential tenure, and home ownership. As such, each of these demographic variables was also measured.

\footnotetext{
${ }^{4}$ The statistical analyses for Hypothesis 2, Hypothesis 3c, and RQ 2c were also run using a civic participation score including only the five offline forms of participation $(M=0.65, S D=1.08, \alpha=.66)$. Excluding the two items asking about circulation of a petition on Facebook and participation in a protest or demonstration on Facebook did not impact the strength or significance of the results of these analyses.
} 


\section{Data Analysis}

Research Question 1 asked about the nature of participants' use of Facebook. This question was answered with basic summary statistics such as range, mean and standard deviation, median, and mode. These statistics provide a general description of intensity of Facebook use, participants' uses and gratifications of Facebook, and connection to micro- and meso-level storytelling on Facebook. Hypothesis 1a and 1b predicted a positive association between overall scope of connection to storytelling and scope of connection to storytelling on Facebook. Hypothesis 2 predicted that the three features of civic engagement — feelings of belonging, collective efficacy, and civic participation - would be positively associated with each other. Hypothesis 3a predicted that integrated connection to a storytelling network (ICSN) on Facebook would be positively associated with feelings of belonging, Hypothesis $3 \mathrm{~b}$ predicted that ICSN on Facebook would be positively associated with collective efficacy, and Hypothesis 3c predicted that ICSN on Facebook would be positively associated with civic participation. Correlation analyses measure the degree to which variables change together (Williams \& Monge, 2001). As such, the associations predicted in Hypotheses 1a through 3c were analyzed with either a Pearson's $r$ or Spearman's rho correlation analysis. If the variables for the analyses were normally distributed, a Pearson's $r$ correlation analysis was used and if the variables were not normally distributed a Spearman's rho correlation analysis was used. The possible moderating role of enjoyment in the relationship between ICSN on Facebook and feelings of belonging (RQ2a), collective efficacy (RQ2b), and civic participation (RQ2b) was explored with ordinary least squares (OLS) 
multiple regression. The significance level for each of these two-tailed tests was set at $\alpha$ $=.05$. All statistical analyses were done in SPSS 21 . 


\section{CHAPTER 4: RESULTS}

RQ 1 asked how participants used Facebook. This research question was investigated by running descriptive statistics on the Facebook intensity questions, enjoyment of using Facebook scale, Facebook use for news scale, uses and gratifications of Facebook scale, the connection to micro- and meso-level storytelling measures, and the items measuring civic participation. These statistics are summarized in four tables: Table 1 provides the summary statistics for each of the Facebook use scales, Table 2 shows the frequency with which participants engaged in communicative acts contributing to micro-level storytelling on Facebook, Table 3 displays the number and proportion of participants who connected with different types of meso-level storytellers on Facebook, and Table 4 summarizes participants' self-reported acts of civic participation.

Participants had an average of 276 total Facebook friends, with approximately one third of those friends (36.2\%) living in their local communities. Most participants reported spending an average of between 15 and 29 minutes on Facebook per day and both enjoyment of using Facebook $(M=3.6$ out of $5, S D=0.9)$ and emotional attachment to Facebook ( $M=3.6$ out of $5, S D=0.8)$ were just above neutral. Participants' use of Facebook for news was moderate $(M=6.0$ out of $10, S D=2.3)$, with obtaining news about current events through friends being the most common use of the site for news ( $M$ $=6.8$ out of $10, S D=2.5$ ). Results of the uses and gratifications measures indicated that social interaction $(M=4.1$ out of $5, S D=0.7)$, habitual pastime $(M=3.6$ out of $5, S D=$ 0.8 ), relaxing entertainment $(M=3.4$ out of $5, S D=0.8)$, and expressive information sharing ( $M=3.2$ out of 5, $S D=0.8)$ were the top uses of Facebook among participants. 
Table 1

Descriptive Statistics for Facebook Use Measures

\begin{tabular}{|c|c|c|}
\hline Facebook Variables & $M$ & $S D$ \\
\hline Total Facebook Friends $^{\mathrm{a}}$ & 276 & 290 \\
\hline Local Facebook Friends ${ }^{b}$ & 100 & 145 \\
\hline Time Spent Using Facebook ${ }^{c}$ & 2.4 & 1.1 \\
\hline Emotional Connection to Facebook ${ }^{\mathrm{d}}$ & 3.6 & 0.8 \\
\hline Enjoyment of Use ${ }^{\mathrm{d}}$ & 3.6 & 0.9 \\
\hline Use for News ${ }^{\mathrm{e}}$ & 6.0 & 2.3 \\
\hline Getting news about current events through & & \\
\hline friends. & 6.8 & 2.5 \\
\hline Staying informed about local community. & 6.0 & 2.7 \\
\hline $\begin{array}{l}\text { Staying informed about current events and } \\
\text { public affairs. }\end{array}$ & 5.9 & 2.8 \\
\hline $\begin{array}{l}\text { Getting news about current events from the } \\
\text { news media. }\end{array}$ & 5.3 & 2.9 \\
\hline Uses \& Gratifications $^{\mathrm{d}}$ & & \\
\hline Social Interaction & 4.1 & 0.7 \\
\hline Habitual Pass Time & 3.6 & 0.8 \\
\hline Relaxing Entertainment & 3.4 & 0.8 \\
\hline Expressive Information Sharing & 3.2 & 0.8 \\
\hline Escapism & 2.8 & 0.9 \\
\hline Cool \& New Trend & 2.8 & 0.9 \\
\hline Companionship & 2.8 & 1.0 \\
\hline To Meet New People & 2.5 & 1.2 \\
\hline Professional Advancement & 2.3 & 1.0 \\
\hline Connection to Micro-Level Storytelling on & & \\
\hline Facebook $^{\mathrm{f}}$ & 5.6 & 2.2 \\
\hline Connection to Meso-Level Storytelling on & & \\
\hline Facebook $^{\mathrm{g}}$ & 3.8 & 2.8 \\
\hline
\end{tabular}

${ }^{a}$ Responses ranged from 0 to 3000 , the mode was $200 .{ }^{b}$ Responses ranged from 0 to 1000, the mode was 50. ${ }^{\mathrm{c}}$ Estimation of the average amount of time per day spent using Facebook: $1=0-14$ minutes, $2=15-29$ minutes, $3=30-59$ minutes, $4=1$ hour or more; the mode was 2.0. ${ }^{\mathrm{d}}$ The emotional connection to Facebook, enjoyment, and uses and gratification response categories ranged from 1 to 5 . ${ }^{\mathrm{e}}$ Facebook use for news response categories ranged from 1 to 10 . ${ }^{\mathrm{f}}$ The theoretical range of the connection to micro-level storytelling variable was 1 to $10 .{ }^{\mathrm{g}}$ The theoretical range of connection to meso-level storytelling was 0 to 8 .

$N=375$

Participants' activities on Facebook facilitated a moderate level of connection to micro-level storytelling $(M=5.6$ out of $10, S D=2.2)$. As shown in Table 2 , the most common way that participants engaged in micro-level storytelling on Facebook was by 
reading friends' status updates about things happening in their neighborhoods $(M=7.0$ out of $10, S D=2.5)$, "liking” friends' status updates about things happing in their neighborhoods $(M=6.5$ out of $10, S D=2.6)$, and commenting on friends' status updates about things happening in their neighborhoods $(M=5.7$ out of $10, S D=2.6)$. While participants' connection to micro-level storytelling on Facebook was moderate, their connection to meso-level storytelling on Facebook was relatively low $(M=3.7$ out of 11 , $S D=2.8$ ). The most common types of community organizations that participants connected with on Facebook were local sports or recreational organizations or clubs (40.8\%), political or educational organizations (42.1\%), and "other" organizations or groups (59.5\%). Reading stories from local newspapers on Facebook (53.3\%) and watching video clips from local television and cable channels $(47.7 \%)$ were the most common ways that participants connected with local media on Facebook. Although consuming content from local media on Facebook was moderate, self-reported levels of sharing local media content were low. Approximately one quarter of the sample shared content from local newspapers (26.9\%) and local television and cable channels $(23.7 \%)$ on Facebook, but only $13.1 \%$ of participants shared sound clips from local radio.

Table 2 Connection to Micro-Level Storytelling on Facebook

\begin{tabular}{lcc}
\hline Communicative Acts on Facebook $^{\mathrm{a}}$ & $M$ & $S D$ \\
\hline Reading Status Updates & 7.0 & 2.5 \\
"Liking" Friends' Status Updates & 6.5 & 2.6 \\
Commenting on Friends' Status Updates & 5.7 & 2.6 \\
Writing Status Updates & 4.3 & 2.6 \\
Writing Posts on Friends' Timelines & 4.7 & 2.7 \\
\hline
\end{tabular}

${ }^{a}$ Participants reported on a 1 (Never) to 10 (All the time) scale the frequency with which they engaged in each of the behaviors while focusing on their neighborhoods. $\mathrm{N}=375$ 
Table 3

Connection to Meso-Level Storytelling on Facebook $(N=375)$

\begin{tabular}{lcc}
\hline Types of Connection & $n$ & Percent (\%) \\
\hline Connection to Community Organizations on & & \\
Facebook & 223 & 59.5 \\
$\quad$ Other organizations or groups & 158 & 42.1 \\
Political or educational organizations & 153 & 40.8 \\
$\quad$ Sports or recreational organizations or clubs & 127 & 33.9 \\
$\quad$ Cultural, ethnic, or religious organizations or & & \\
$\quad$ groups & 82 & 21.9 \\
Neighborhood group or homeowners' association & & \\
Consuming Content From Local Media on Facebook & 200 & 53.3 \\
$\quad$ Local newspapers & 179 & 47.7 \\
Local television \& cable channels & 77 & 20.5 \\
$\quad$ Local radio stations & & \\
Sharing Content From Local Media on Facebook & 101 & 26.9 \\
$\quad$ Local newspapers & 89 & 23.7 \\
Local television \& cable channels & 49 & 13.1 \\
$\quad$ Local radio stations & & \\
\hline
\end{tabular}

Table 4

Civic Participation $(N=375)$

\begin{tabular}{lcc}
\hline Participatory Behaviors & $n$ & Percent (\%) \\
\hline $\begin{array}{l}\text { Attended a city council meeting, public hearing, or } \\
\quad \text { neighborhood council meeting. }\end{array}$ & 77 & 20.5 \\
Contacted an elected official about a problem? & 64 & 17.1 \\
Took part in a political demonstration or protest on Facebook. & 60 & 16.0 \\
Circulated a petition on Facebook. & 56 & 14.9 \\
Wrote a letter to the editor of a newspaper, television station, & 34 & 9.1 \\
$\quad$ or magazine. & 36 & 9.6 \\
Took part in a political demonstration or protest offline. & 32 & 8.5 \\
Circulated a petition offline. & & \\
\hline
\end{tabular}

Although overall levels of civic participation were low $(M=0.96$ out of $7, S D=$ 1.49), participants did report using Facebook as a forum for civic action. Taking part a political demonstration or protest on Facebook (16.0\%) and circulating a petition on Facebook (14.9\%) were among the most highly reported acts of participation. As shown in Table 4, levels of participation in these online civic actions were just behind the most common forms of offline civic participation - attending a city council meeting, public 
hearing, or neighborhood council meeting (20.5\%) and contacting an elected official about a problem $(17.1 \%)^{5}$.

Hypothesis 1a predicted that scope of connection to overall micro-level storytelling would be positively associated with scope of connection to micro-level storytelling on Facebook while Hypothesis $1 \mathrm{~b}$ predicted that scope of connection to overall meso-level storytelling would be positively associated with scope of connection to meso-level storytelling on Facebook. The positive correlations predicted in Hypotheses 1a and 1b were both tested with Pearson's $r$ correlation analyses because the micro- and meso-level storytelling variables were normally distributed. Hypothesis 1a was supported as there was a statistically significant positive correlation between overall scope of connection to micro-level storytelling and scope of connection to micro-level storytelling on Facebook, $r(373)=.42, p<.001$. The relationship was such that higher levels of overall connection to micro-level storytelling $(M=4.44$ out of $10, S D=2.39)$ were associated with higher levels of connection to micro-level storytelling on Facebook $(M=5.61$ out of $10, S D=2.16)$. Hypothesis $1 \mathrm{~b}$ was also supported. The Pearson's $r$ correlation analysis revealed that there was a statistically significant positive correlation between overall connection to meso-level storytelling and connection to meso-level storytelling on Facebook, $r(373)=.57, p<.001$. Again, higher levels of overall connection to meso-level storytelling $(M=3.67$ out of $8, S D=2.04)$ were associated with

\footnotetext{
${ }^{5}$ To gauge whether levels of civic participation among this sample were typical, results were compared to similar items on a 2012 survey conducted for Pew Research Center's Internet \& American Life Project. Although results are not directly comparable because the Pew survey asked about participation during the past 12 months and this survey asked about participation since moving to their current neighborhood, results from Pew's survey with a national sample of 2,253 were as follows: $22 \%$ of participants reported attending a political meeting on local, town or school affairs, $21 \%$ reported contacting an elected official about a problem, $6 \%$ reported attending an organized demonstration or protest, and $3 \%$ reported sending a letter to the editor of a newspaper or magazine (Smith, 2013).
} 
higher levels of connection to meso-level storytelling on Facebook ( $M=3.83$ out of 11 , $S D=2.78)$

Hypothesis 2 predicted that feelings of belonging, collective efficacy, and civic participation - the three constitutive variables of civic engagement for CIT researchwould be positively associated with each other. The associations were tested with Spearman's rho correlation analyses because civic participation was measured at the ordinal level and was not normally distributed. The hypothesis was supported as neighborhood belonging, collective efficacy, and civic participation were all statistically significantly positively correlated with each other. The correlation statistics are summarized in Table $5^{6}$.

Table 5

Spearman's rho Correlations, Means, and Standard Deviations of Civic Engagement Variables $(N=375)$

\begin{tabular}{lccc}
\hline Variables & $M(S D)$ & $\begin{array}{c}\text { Neighborhood } \\
\text { Belonging }\end{array}$ & $\begin{array}{c}\text { Collective } \\
\text { Efficacy }\end{array}$ \\
\hline Neighborhood Belonging $^{\mathrm{a}}$ & $17.32(7.21)$ & & \\
Collective Efficacy $^{\mathrm{b}}$ & $2.47(0.94)$ & $.61^{* * *}$ & $.22^{* * *}$ \\
Civic Participation $^{\mathrm{c}}$ & $1.00(1.49)$ & $.26^{* * *}$ & $.20 .{ }^{\mathrm{b}} \mathrm{Th}$
\end{tabular}

${ }^{\mathrm{a}}$ The theoretical range of the neighborhood belonging variable was 5 to $40 .{ }^{\mathrm{b}}$ The theoretical range of the collective efficacy variable was 1 to $5 .{ }^{\mathrm{c}}$ The theoretical range of the civic participation variable was 0 to 7 .

$* p<.05 ; * * p<.01 ; * * * p<.001$

Hypotheses $3 \mathrm{a}$ through $3 \mathrm{c}$ were all supported. Hypothesis $3 \mathrm{a}$ predicted that integrated connection to a storytelling network (ICSN) on Facebook would be positively associated with feelings of neighborhood belonging. The relationship between these two

\footnotetext{
${ }^{6}$ Spearman's rho correlation analyses testing the relationship between a measure of civic participation including only traditional, offline activities yielded the same result for the relationship between civic participation and feelings of neighborhood belonging. The association between a measure of civic participation including only the traditional, offline activities and collective efficacy was slightly weaker, $r_{s}$ $(373)=.21, p<.001$.
} 
normally distributed variables was tested with a Pearson's $r$ correlation analysis and a statistically significant positive correlation was found, $r(373)=.35, p<.001$. Similarly, Hypothesis $3 \mathrm{~b}$ predicted that ICSN on Facebook would be positively associated with collective efficacy. This relationship was also tested with a Pearson's $r$ correlation analysis and a statistically significant positive correlation was found, $r(373)=.23, p<$ .001. Finally, the prediction that ICSN on Facebook would be positively associated with civic participation for Hypothesis 3c was tested with a Spearman's rho correlation analysis because civic participation was measured at the ordinal level and was not normally distributed. Again, a statistically significant positive correlation was found, $r_{S}$ $(373)=.41, p<.001^{7}$. In sum, higher ICSN on Facebook scores $(M=8.42$ out of $15, S D$ $=3.37)$ were associated with stronger feelings of neighborhood belonging $(M=17.32$ out of $40, S D=7.21)$, stronger collective efficacy $(\mathrm{M}=2.46$ out of $5, S D=0.94)$, and higher levels of civic participation $(M=0.96$ out of $7, S D=1.49)$.

RQ 2a through 2c asked whether enjoyment of using Facebook moderates the relationship between ICSN on Facebook and (a) feelings of belonging, (b) collective efficacy, and (c) civic participation. These research questions were tested with OLS multiple regression analyses. Preliminary data analyses revealed that race, income, length of residence in a community, and home ownership were significant predictors of at least one of the CIT civic engagement variables. As such, these variables were controlled for in the first step of each analysis. Race, income, length of residence in a community,

\footnotetext{
${ }^{7}$ The relationship between civic participation and ICSN on Facebook was also tested using a measure of civic participation including only traditional, offline activities. Excluding the measures of civic participation on Facebook did not affect the strength or significance of the association between the ICSN on Facebook and civic participation.
} 
and home ownership accounted for $6.9 \%$ of the variance in feelings of neighborhood belonging $\left(\mathrm{R}^{2}=.07, p<.001\right), 5.6 \%$ of the variance in collective efficacy $\left(\mathrm{R}^{2}=.07, p<\right.$ $.01)$, and $4.6 \%$ of the variance in civic participation $\left(\mathrm{R}^{2}=.05, p<.05\right)$.

Table 6 OLS Regression Predicting Neighborhood Belonging, Collective Efficacy, and Civic Participation

\begin{tabular}{|c|c|c|c|}
\hline & $\frac{\text { Neighborhood }}{\text { Belonging }}$ & $\frac{\text { Collective }}{\text { Efficacy }}$ & $\frac{\text { Civic }}{\text { Participation }}$ \\
\hline Independent Variables & $\beta$ & $\beta$ & $\beta$ \\
\hline \multicolumn{4}{|l|}{ Model 1} \\
\hline African American & $0.15^{* *}$ & 0.07 & 0.08 \\
\hline Hispanic & -0.03 & 0.05 & -0.01 \\
\hline Asian & -0.01 & 0.01 & -0.09 \\
\hline Other Race & 0.03 & -0.02 & 0.05 \\
\hline Income & -0.06 & $0.12 *$ & -0.06 \\
\hline $\begin{array}{l}\text { Years Residence in } \\
\text { Community }\end{array}$ & $0.12 *$ & 0.03 & $0.16^{* *}$ \\
\hline Own Home & $0.16^{* *}$ & $0.17 * *$ & 0.05 \\
\hline $\mathrm{R}^{2}(\%)$ & $6.9 * * *$ & $6.6 * *$ & $4.6 * *$ \\
\hline
\end{tabular}

\section{Model 2}

African American

$0.10^{*}$

0.03

0.02

Hispanic

$-0.02$

0.05

$-0.01$

Asian

0.01

0.01

$-0.06$

Other Race

0.02

$-0.03$

0.04

Income

$-0.02$

$0.14 * *$

$-0.03$

Years Residence in

0.08

$-0.01$

0.10

Community

Own Home

$0.13 *$

$0.16 * *$

0.04

Enjoyment of Using

Facebook

$0.11^{*}$

0.02

$-0.02$

ICSN on Facebook

$0.28 * * *$

$0.23 * * *$

$0.38 * * *$

$\mathrm{R}^{2}(\%)$

$16.9 * * *$

$11.8 * * *$

$17.7 * * *$

\section{Model 3}

$\begin{array}{lccr}\text { African American } & 0.10^{*} & 0.03 & 0.02 \\ \text { Hispanic } & -0.02 & 0.05 & -0.01 \\ \text { Asian } & 0.01 & 0.01 & -0.06 \\ \text { Other Race } & 0.02 & -0.03 & 0.04 \\ \text { Income } & -0.02 & 0.14^{* *} & -0.02 \\ \text { Years Residence in } & 0.08 & -0.01 & 0.09\end{array}$


Community

Own Home

Enjoyment of Using

Facebook

ICSN on Facebook

ICSN on Facebook $\mathrm{x}$

Enjoyment
$0.13 *$

0.03

0.12

0.20
$0.16 * *$

0.02

0.23

0.01
0.04

$-0.03$

0.35

0.03

\begin{tabular}{lccc}
\hline $\mathrm{R}^{2}(\%)$ & 17.0 & 11.8 & 17.7 \\
\hline Note. White was the reference category for the dummy-coded race variable. & There was
\end{tabular}
no evidence of serious multicollinearity issues as VIF statistics were less than 10 and tolerance statistics were greater than 0.10 for each of the predictors included in the models.

$* \mathrm{p}<.05 ; * * \mathrm{p}<.01 ; * * * \mathrm{p}<.001$

Enjoyment of using Facebook and ICSN on Facebook were added to the models

in the second step of the analyses for RQ 2. As shown in Table 6, the addition of these two variables resulted in a statistically significant increase in the amount of variance in neighborhood belonging explained by the model for RQ 2a, $\mathrm{R}^{2}$-change $=.15, p<.001$. After controlling for demographic variables and ICSN on Facebook, enjoyment of using Facebook was a significant predictor of neighborhood belonging, $\beta=0.11, p<.05$.

ICSN on Facebook was also a significant predictor of feelings of neighborhood belonging after controlling for demographics and enjoyment of using Facebook, $\beta=0.28, p<.001$. The second step in the analysis also resulted in a statistically significant increase in the amount of variance in collective efficacy explained by the model for RQ $2 b, R^{2}$-change $=$ $.10, p<.001$. Although enjoyment of using Facebook was not a significant predictor of collective efficacy after controlling for other variables, ICSN on Facebook was a significant predictor of collective efficacy after controlling for other variables, $\beta=0.23, p$ $<.001$. Again, the amount of variance in civic participation explained by the model for RQ 2c increased, $\mathrm{R}^{2}$-change $=.13, p<.001$. After controlling for other variables, 
enjoyment of using Facebook was not a significant predictor of civic participation, but ICSN on Facebook was, $\beta=0.38, p<.001$.

Finally, the moderating role of enjoyment of using Facebook was tested in the third step of the analyses. As shown in Table 6, the interaction term between ICSN on Facebook and enjoyment of using Facebook was not a significant predictor of neighborhood belonging, collective efficacy, or civic participation after controlling for other variables. As such, there is no evidence that enjoyment of using Facebook moderates the relationship between ICSN on Facebook and neighborhood belonging (RQ 2a), collective efficacy (RQ 2b), or civic participation (RQ 2c) ${ }^{8}$.

\section{Post Hoc Analyses}

Hypotheses $1 \mathrm{a}$ and $1 \mathrm{~b}$ predicted that overall connection to micro- and meso-level storytelling would be associated with connection to micro- and meso-level storytelling on Facebook. To confirm that the association extended to the ICSN variables, a post hoc Pearson's $r$ correlation analysis was run to test whether overall ICSN was positively associated with ICSN on Facebook. A statistically significant positive correlation was found, $r(373)=.56, p<.001$. As was expected based on the positive associations found for Hypothesis 1a and 1b, higher overall ICSN scores $(M=8.10$ out of $15, S D=2.93)$ were associated with higher ICSN on Facebook scores $(M=8.41$ out of $15, S D=3.37)$.

A post hoc simple OLS regression analysis was also conducted to determine if any of the specific uses of Facebook measured by the uses and gratifications of Facebook scale and the Facebook use for news scale significantly predicted ICSN on Facebook.

\footnotetext{
${ }^{8}$ The regression model for RQ $2 \mathrm{c}$ was also run including only traditional, offline forms of civic participation. Excluding the two Facebook activities did not affect the results of the analysis.
} 
This analysis was conducted to determine if the significant relationships between specific media uses and civic engagement found by past research (e.g., Moy, Manosevitch, Stamm, \& Dunsmore, 2003; Scheufele \& Nisbet, 2002; Shah, Cho, Eveland, \& Kwak, 2005) were also true for the relationships between specific media uses and ICSN on Facebook. Together, the nine dimensions of the uses and gratifications of Facebook scale and Facebook use for news accounted for $35.4 \%$ of the variance in ICSN on Facebook, $\mathrm{R}^{2}=.35, p<.001$. As shown in Table 7 , after controlling for other uses of Facebook, use of the site for expressive information sharing $(\beta=0.19, p<.01)$, professional advancement $(\beta=0.13, p<.05)$, and news $(\beta=0.39, p<.001)$ significantly predicted ICSN on Facebook.

Table 7 OLS Regression predicting ICSN on Facebook

\begin{tabular}{lccc}
\hline Independent Variables & $B(\mathrm{SE})$ & $\beta$ & $p$ \\
\hline News Gathering & $0.57(0.08)$ & $0.39^{* * *}$ & .00 \\
Expressive Information Sharing & $0.75(0.22)$ & $0.19^{* *}$ & .00 \\
Professional Advancement & $0.44(0.18)$ & $0.13^{*}$ & .01 \\
Relaxing Entertainment & $0.19(0.24)$ & 0.05 & .43 \\
Escapism & $0.13(0.22)$ & 0.04 & .55 \\
Cool \& New Trend & $-0.20(0.19)$ & -0.06 & .30 \\
Companionship & $-0.07(0.17)$ & -0.02 & .69 \\
Social Interaction & $0.19(0.25)$ & 0.04 & .45 \\
Habitual Pass Time & $0.17(0.26)$ & 0.04 & .52 \\
To Meet New People & $0.04(0.15)$ & 0.01 & .79 \\
\hline $\mathrm{R}^{2}(\%)$ & & $35.4^{* * *}$ & .00 \\
\hline
\end{tabular}

Note. There was no evidence of serious multicollinearity issues as VIF statistics were less than 10 and tolerance statistics were greater than 0.10 for each of the predictors included in the model.

$* \mathrm{p}<.05 ; * * \mathrm{p}<.01 ; * * * \mathrm{p}<.001$ 


\section{CHAPTER 5: DISCUSSION}

Recognizing the importance of civic engagement to the health of local communities and the overall success of a democracy, this research sought to better understand the relationship between online media use and civic engagement. Specifically, the constructive potential of the social networking site Facebook was explored using the theoretical framework of communication infrastructure theory (CIT; Ball-Rokeach, Kim, \& Matei, 2001). Data describing participants' Facebook use, results indicating that Facebook facilitates connection to storytelling, and results demonstrating a relationship between connection to storytelling on Facebook and feelings of neighborhood belonging, collective efficacy, and civic participation highlight the affordances and limitations of Facebook for facilitating civic engagement. The following sections explain the findings and discuss implications for Facebook's potential to increase social capital and encourage civic engagement.

\section{Describing Facebook Use}

A central premise of CIT is that the development of community is rooted in the communicative resources that are available for storytelling about the community (Kim \& Ball-Rokeach, 2006a). The importance of storytelling resources to the development of local community prompted the first research question for this study, which explored participants' uses of Facebook. Data from the Facebook intensity questions, enjoyment of using Facebook scale, Facebook use for news scale, uses and gratifications of Facebook scale, the connection to micro- and meso-level storytelling measures, and civic 
participation items were examined to gain insight into participants' use of the site in a changing communication landscape.

Although participants did not report high levels of emotional attachment to Facebook or strong general enjoyment of their user experience, most reported using the site for an average of 15 to 29 minutes a day. Participants reported using the site for social interaction, habit, and to share information. It was relatively common for participants to learn about current events through friends on Facebook and connections to micro- and meso-level storytelling on the site were moderate. On average, local ties on Facebook accounted for approximately one third of participants' total Facebook friend network. Cumulatively, the dynamics of participants' Facebook use suggest a number of ways in which the site, as a communicative resource, may facilitate civic engagement.

Participants' neutral levels of attachment to and enjoyment of Facebook coupled with regular use may suggest that the site is a taken-for-granted part of their daily routine. Indeed, many participants reported that they used the site out of habit. Regularity of Facebook use is important to consider because it indicates that Facebook is a medium with which participants are accustomed to spending time. Regularity of use is particularly relevant when considered in relation to the positive correlations found for Hypotheses 1 and 3. The positive correlations between overall connection to storytelling and connection storytelling on Facebook indicate that Facebook does facilitate connection to storytelling. Furthermore, the positive associations between ICSN on Facebook and the CIT civic engagement variables indicate that ICSN on Facebook is positively related to civic engagement. Based on these positive associations, participants' 
familiarity with the medium and regular use may hold potential for positive incidental impacts on civic engagement.

The highest rated use of Facebook among participants was social interaction and it was rare for participants to use the site to meet new people. Together, these results indicate that participants used the site to maintain existing social connections. Although this research did not inquire about the nature of participants' connection with their Facebook friends, past research has found that the site plays an important role in forming and maintaining social capital among college students (Ellison, Steinfield, Lampe, 2007). Considering that civic engagement depends on the social capital of individual and network relations for collective action (Rohe, 2004), participants' use of the site to maintain existing social connections may point to another aspect of the site's potential to facilitate civic engagement.

While participants' use of the site to maintain social connections may foster social capital, it is also important to consider with whom participants were in contact. Civic engagement is largely place-bound. As such, the greater proportion of distant connections maintained on Facebook may suggest a limitation on the site's potential to encourage civic engagement. While a greater proportion of participants' Facebook friends were distant connections, most participants reported that about 50 of their Facebook friends resided in their local communities. Connection to 50 individuals in one's local community does hold potential. The local connections maintained through the site and the convenience of access may make it an ideal forum to develop and practice the communication and organization skills that Brady, Verba, and Schlozman (1995) 
identified as essential precursors to participation. Facebook may act as a nonpolitical setting, like the churches and community organizations discussed by Brady et al. (1995), that provides a low-risk environment to practice communication skills while also making it easier to obtain information, connect with people, and learn about the tools needed to engage in the offline local community.

Participants' use of Facebook to connect with micro- and meso-level storytelling is another important feature of the site's potential. Participants reported regular participation in micro-level storytelling on Facebook by reading and "liking" friends" status updates about happenings in their neighborhoods, moderate levels of connection to community organizations on Facebook, and moderate consumption of content from local newspapers and television. Furthermore, participants' most common use of Facebook for news was learning about current events through friends. CIT identifies storytelling as instrumental to civic engagement and these moderate levels of connection to micro- and meso-level storytelling demonstrate that Facebook does have the potential to facilitate connection to storytelling networks and contact between storytellers. This use of Facebook is particularly important as correlation analyses for Hypotheses 3a through 3c found significant positive associations between connection to storytelling and feelings of neighborhood belonging, collective efficacy, and civic participation. While participants reported moderate levels of consuming local storytelling on Facebook, levels of production and distribution of local storytelling were low. Participants reported low levels of writing status updates and timeline posts about neighborhood happenings and 
similarly low levels of sharing local news content, indicating that most participants adopted a passive role in engaging with local storytelling.

Participants also used Facebook to engage in two of the top four forms of civic participation among this sample: taking part in a political demonstration or protest on Facebook and circulating a petition on Facebook. As Gladwell (2010) argues, these acts of participation on Facebook are not as high-stakes as offline social activism. However, it may be hasty to disregard them as trivial or counterproductive. Rather than fostering complacency by conditioning individuals for low-stakes involvement in their communities as argued by Gladwell (2010), civic participation on Facebook may be a precursor to action in the offline world (Bennett, 2008; Raynes-Goldie \& Walker, 2008). A recent study conducted by the Pew Research Center's Internet \& American Life Project found that $43 \%$ of social media users decided to learn more about a political or social issue because of something they read on social media and $18 \%$ of social media users took offline action on a social or political issue after learning about it on social media (Smith, 2013).

\section{Facebook in the Communication Infrastructure}

Preliminary insights into the potential of Facebook provided by descriptive data about participants' Facebook use are enriched by results situating Facebook within participants' communication infrastructures. Results from Hypotheses $1 \mathrm{a}$ and $1 \mathrm{~b}$ and a post hoc analysis regressing specific uses of Facebook on the ICSN on Facebook variable support and extend CIT research, social media research, and media use research. Results from Hypotheses 1a and 1b extend CIT by demonstrating that Facebook facilitates 
integrated connection to a storytelling network and that storytelling is dynamic across storytelling forums. These findings also support and extend new media research by highlighting Facebook's ability to contribute to civic engagement by facilitating storytelling. Meanwhile, results of the post hoc regression analysis provide new insight into media use research by demonstrating that connection to storytelling may be an important intermediate variable that explains relationships between specific uses of media and civic engagement.

Results indicated that overall connection to storytelling was associated with connection to storytelling on Facebook. As expected, correlation analyses for Hypotheses $1 \mathrm{a}$ and $1 \mathrm{~b}$ indicated that connection to overall micro- and meso-level storytelling was significantly positively associated with connection to micro- and mesolevel storytelling on Facebook. Post hoc analysis also confirmed that overall ICSN was significantly positively associated with ICSN on Facebook. These strong associations were expected based on findings from past research indicating that the thorough integration of online media into our daily lives makes it difficult to recall whether the source of information was offline or online (Bimber, 2000). These results also extend CIT. CIT theorizes that integrated connection to neighborhood storytelling is dynamic at the individual level insofar as connection to one storyteller stimulates connection to other neighborhood storytellers (Kim \& Ball-Rokeach, 2006a). The strong associations observed between overall connection to storytelling and connection to storytelling on Facebook extend understanding of the dynamism of integrated storytelling by demonstrating that connection also translates across storytelling forums. 
These results also contribute to the developing body of research demonstrating that social networking sites may hold potential for civic engagement (e.g., Pasek, more, \& Romer, 2009; Gil de Zuniga, Jung, \& Valenzuela, 2012; Kim, Hsu, \& Gil de Zuniga, 2013). The positive associations demonstrate that time spent on Facebook did not detract time and energy that participants might otherwise have spent engaging with their local communities, as an extension of Putnam's (2000) time displacement hypothesis would suggest. Furthermore, as Matei and Ball-Rokeach (2003) emphasized in their discussion of the role of the internet as a meso-linkage in a community's communication infrastructure, Facebook cannot, by itself, have a strong positive impact on the storytelling dynamics of a community. Rather, as one of several possible linkages within a community, it holds the potential to contribute to the strengthening or weakening of the communication infrastructure. The positive associations between overall connection to storytelling and connection to storytelling on Facebook suggest that the site facilitates connections to storytelling networks, which may be indicative of its potential to encourage civic engagement.

While the strong associations between overall connection to storytelling and connection to storytelling on Facebook provide insight into an aspect of the constructive potential of Facebook for civic engagement, these results may also indicate that the site benefits those who are already well connected to storytelling. Past media use research has found that individuals who are already well connected and engaged are most likely to enjoy a boost in social capital and increased civic engagement from media use (Norris, 2001). In his discussion of the relationship between internet use and feelings of 
neighborhood belonging, Matei (2001) described this phenomenon as a magnifying glass effect. In essence, it is possible that Facebook use strengthens connection to neighborhood storytelling for individuals' who are already immersed in a rich storytelling network and weakens anchoring to local storytelling among people with frail connections to a storytelling network. The potential of such an effect on Facebook is heighted by the nature of the way the site's News Feed algorithm determines top stories and the level of control that users have to sort and filter their News Feeds. Comparison of mean scores reveals that participants' overall connection to meso-level storytelling was proportionally stronger than their connection to meso-level storytelling on Facebook. This result may be indicative of a magnifying glass effect. However, comparison of means scores for microlevel storytelling reveals that connection to micro-level storytelling was stronger on Facebook than overall connection to micro-level storytelling. This finding may indicate that Facebook has unique affordances that extend connection to micro-level storytelling rather than simply reinforcing existing connections.

Results of a post hoc regression analysis indicate that using Facebook for expressive information sharing, professional advancement, and news gathering was associated with stronger ICSN on Facebook. These results support past media use research finding that using media to gain or share information is consistently associated with higher levels of civic engagement while using media for entertainment is not (Moy, Manosevitch, Stamm, \& Dunsmore, 2003; Scheufele \& Nisbet, 2002; Shah, Cho, Eveland, \& Kwak, 2005). The uses of Facebook that were associated with higher ICSN on Facebook were reflective of information gathering or information sharing. As such, 
although ICSN does not always translate directly into civic engagement, this finding is in keeping with past media use research and may suggest that connection to storytelling is an important intermediate variable that can help to explain the relationship between specific uses of media and civic engagement.

\section{Storytelling and Civic Engagement}

Facebook's ability to facilitate storytelling is an essential aspect of its potential because connection to neighborhood storytelling is central to civic engagement. Results of this study confirm the theorized relationship between the three constitutive elements of civic engagement identified by CIT — feelings of neighborhood belonging, collective efficacy, and civic participation — and results of correlation analyses demonstrate that connection to storytelling on Facebook was positively related to the civic engagement variables. These results both highlight the constructive potential of Facebook for civic engagement and indicate that a key aspect of this potential is the site's ability to facilitate neighborhood storytelling.

CIT theorizes a dynamic relationship between feelings of neighborhood belonging, residents' trust in their community's capacity to mobilize and work collectively to solve neighborhood issues, and the actual time and money residents dedicate to solving these issues (Kim \& Ball-Rokeach, 2006a). The correlation analyses for Hypothesis 2 confirmed this theorized relationship. Hypothesis 2 predicted that feelings of neighborhood belonging, collective efficacy, and civic participation would be associated with one another. The strength of the relationships between variables also confirmed the specifics of the relationships predicted by CIT. The theoretical model of 
CIT predicts that connection to local storytellers first increases feelings of belonging and collective efficacy which, in turn, increase the likelihood of civic participation (Kim \& Ball-Rokeach, 2006a). As predicted by CIT, the relationship between neighborhood belonging and perceived collective efficacy was strong, with weaker associations observed between civic participation and neighborhood belonging and civic participation and collective efficacy. A possible explanation for the lower associations with civic participation is that mean levels of civic participation were lower than mean levels of belonging and efficacy because participation requires access to resources (McCarthy \& Zald, 1977). Feelings of belonging, collective efficacy, and connection to a storytelling network increase the likelihood that individuals have access to these resources, but do not ensure action (Kim \& Ball-Rokeach, 2006a).

While the low levels of civic participation reported by participants may be discouraging, they reinforce the argument for the importance of adopting a broader conceptualization of civic engagement. Rather than equating civic engagement with traditional forms of civic participation as some past research has done (e.g., Delli Carpini, 2000; Putnam, 2000), the multi-dimensional measure of civic engagement used for CIT research allows for a more nuanced understanding of the factors that coalesce to produce civic engagement. This more nuanced picture may be instrumental to strategic efforts to increase civic engagement because the model provides the capacity to identify current ways of engaging and parse out areas of strength to build upon. An understanding of current ways of engaging and current areas of strength may be particularly useful for strategic interventions designed to increase civic engagement through behavior change. 
Results of the correlation analyses for Hypotheses 3a through 3c support CIT's claim that access to community storytelling is a critical factor in civic engagement (Kim \& Ball-Rokeach, 2006a). ICSN on Facebook was significantly positively associated with feelings of neighborhood belonging, collective efficacy, and civic participation. ICSN was most strongly associated with feelings of neighborhood belonging, which supports CIT's identification of neighborhood belonging as the most essential part of civic engagement (Kim \& Ball-Rokeach, 2006a). The next strongest relationship was between ICSN on Facebook and collective efficacy, followed by the relationship between ICSN on Facebook and civic participation.

The varying strength of the correlations between ICSN on Facebook and the civic engagement variables demonstrates that the relationship between connection to storytelling and feelings of belonging, collective efficacy, and civic participation is somewhat iterative. CIT theorizes that neighborhood belonging is an essential precursor to civic engagement. Through discourse about the local community, individuals construct a collective identity and begin to feel like they belong by thinking of themselves as residents of that community (Ball-Rokeach et al., 2001). Through connections to storytelling, individuals are also more likely to know what they can and should do to address community issues and where they can find the help and resources they need to produce the desired outcomes (Kim \& Ball-Rokeach, 2006a). While neighborhood belonging and collective efficacy are theorized to develop more or less commensurately, civic participation does not always follow because it is only possible with access to necessary resources (Kim \& Ball-Rokeach, 2006a). 
The associations between ICSN on Facebook and neighborhood belonging, collective efficacy, and civic participation also extend CIT by demonstrating that Facebook can facilitate the types of connection to micro- and meso-level storytelling that are essential to civic engagement. Although participants' connection to micro- and mesolevel storytelling on Facebook were only moderate, these connections were associated with increased neighborhood belonging, collective efficacy, and civic participation. These positive associations demonstrate that the site does have potential for encouraging civic engagement.

Regression analyses examining whether enjoyment of using Facebook moderates the relationship between ICSN on Facebook and the civic engagement variables provide additional insight into the nature of the relationship between connection to storytelling on Facebook and civic engagement. RQ 2a through 2c asked whether enjoyment of using Facebook moderated the relationship between ICSN on Facebook and feelings of neighborhood belonging, collective efficacy, and civic engagement. Past research has found positive associations between enjoyment of media use and civic engagement (Coleman, Lieber, Mendelson, \& Kurpius, 2008) and political knowledge (Nash \& Hoffman, 2009). Although enjoyment has not been explored from a CIT perspective, it was expected that the convenience and ease of making and maintaining connections on Facebook might contribute to higher levels of enjoyment of the process of staying connected to an integrated storytelling network and thereby moderate the relationship between ICSN on Facebook and the three CIT civic engagement variables. Results of the 
three multiple regression analyses, however, provided no evidence that enjoyment does moderate these relationships.

One possible explanation for the non-significant results is that enjoyment was not the appropriate operationalization to test the relationship. Rather than enjoyment, measures of convenience, accessibility, or effectiveness might have better captured the aspects of Facebook use that affect participants' enjoyment of the process of connecting to an integrated storytelling network on Facebook. Another possible explanation for the non-significant results is that the measure of enjoyment employed for this study was not sufficiently detailed. The scale was borrowed from Lin and Lu (2011) and was highly reliable in this sample, but it only asked about participants' affective response to using Facebook. In 2004, Nabi and Krcmar argued media enjoyment is best conceived as a "three-dimensional construct comprised of affective, cognitive, and behavioral information that mutually exert influence on one another" (p. 296). They argued that this more nuanced conceptualization of enjoyment can help to explain seemingly contradictory effects of media enjoyment. When a more refined measure of enjoyment that measures these three aspects is developed and validated, it might provide better insight into the possible role of enjoyment in the relationship between ICSN on Facebook and neighborhood belonging, collective efficacy, and civic participation.

\section{Limitations \& Future Research}

These results demonstrating the constructive potential of Facebook for civic engagement should be considered in light of a number of limitations. One of the primary limitations of this study is that it relied on cross-sectional survey data. Measuring 
Facebook use, connection to storytelling, and civic engagement over time would provide better understanding of the role of Facebook in civic engagement. Longitudinal data would also provide better insight into the sequential nature of the relationship between connection to a storytelling network, neighborhood belonging, and civic participation. This cross-sectional data supports the hypothesized sequence that connection to storytelling leads to feelings of belonging and collective efficacy which increase the likelihood of increased civic participation (Kim \& Ball-Rokeach, 2006a). However, this theorized relationship cannot be confirmed without longitudinal data.

Another limitation of this study is that it only focused on individual Facebook users. One consequence of this narrow focus was that it did not allow for a comparison of connection to neighborhood storytelling between Facebook users and non-Facebook users. Such a comparison would provide valuable insight into the magnitude of the potential of Facebook for facilitating civic engagement. Another consequence of this narrow focus was that it only measured micro-level storytellers' uses of Facebook. Future research should consider how community organizations and local media use the site to gain a fuller understanding of Facebook's potential to facilitate storytelling. A third consequence of this narrow focus was that it did not examine other social networking sites. While this narrow focus provided rich data on how current Facebook users engaged with storytelling on the site, future research should consider multiple social networking sites, compare users and non-users, and measure local media and community organizations' use to gain a more complete understanding of how social 
networking sites impact communities' communication infrastructures and explore their potential for encouraging civic engagement.

Findings from this study prompt a number of interesting questions that future research should explore. The moderate to low levels of consuming, producing, and sharing micro- and meso-level storytelling among this sample indicate that Facebook may hold untapped potential for civic engagement. Future research should explore what motivates people to engage in more active forms of storytelling on Facebook.

Understanding these motivations may, in turn, inform the design and testing of strategic efforts to encourage Facebook users to engage in such behaviors more regularly. Another possibility for future research would be to draw on theories of behavior change to develop strategic interventions that reinforce and extend feelings of neighborhood belonging and collective efficacy to increase civic participation and improve overall civic engagement. Furthermore, the finding that connection to micro-level storytelling on Facebook was higher than overall connection micro-level storytelling among this sample may indicate that Facebook has the capacity to extend connection to micro-level storytelling rather than simply reinforcing existing connections. Future research should examine this possibility. In light of participants' use of Facebook to engage in acts of civic participation, future research should also explore whether online forms of engagement translate into the offline world.

The literature would also be enriched by research examining the role of social networking sites in the context of specific communities. A general national approach was adopted for this research to gain preliminary insight into the constructive potential of 
Facebook for civic engagement. While this general approach provided useful preliminary insight, it is limited by the fact that it did not consider the communication action context (CAC). The CAC makes it harder or easier for individuals and communities to have strong, integrated storytelling networks (Kim \& Ball-Rokeach, 2006a). As such, future research should narrow the focus to individual communities to examine how social media operate in the communication infrastructures of communities that vary by degree of openness and closedness. Community information shared on social networking sites does not necessarily stay local. As such, it would be interesting to explore how exposure to community-based information for non-local connections on social networking sites impacts users' connection and feelings of belonging to their own local communities. A related direction for future research would be to investigate the relationship between feelings of belonging to place-bound community as opposed to feelings belonging to online communities. Such an approach might provide new insight into the ways in which online connections facilitate and/or inhibit the translation of online social capital to offline social capital and civic engagement. Finally, findings from this study can be applied and extended in future research to develop and validate more comprehensive measures to assess how social networking sites contribute to communities' communication infrastructures. It would be particularly fruitful to develop measures that focus on common attributes across social networking sites, rather than on specific sites.

\section{Conclusion}

Civic engagement has long been regarded an important feature of American democracy. Because of its importance to the vitality of American democracy as well as 
the health and functioning of our local communities, it is important to consider ways to reinforce current levels of engagement as well as seek ways to encourage new engagement. As social networking sites have become more pervasive, they have also become increasingly central to the ways that citizens choose to engage (Bennett, 2008). While this reality has prompted some to celebrate the potential of social media for civic engagement, others are skeptical. Acknowledging the value in both perspectives, the present study employed communication infrastructure theory (Ball-Rokeach et al., 2001) to conduct a measured assessment of the affordances and limitations of Facebook for encouraging civic engagement.

Results provided support for cautious optimism that Facebook does hold potential for facilitating civic engagement. The two most important findings of this research were that Facebook facilitated connection to neighborhood storytelling and that this connection was associated with civic engagement. In short, findings suggested that a key aspect of Facebook's potential for civic engagement is the site's ability to facilitate connection to local storytelling. In light of this potential, specific details of participants' Facebook use suggest a number of ways in which the site, as a communicative resource, facilitates civic engagement. Facebook holds potential as a channel for neighborhood storytelling, a regular part of users' daily routines, a means to maintain social capital, and a forum for occasional civic participation. Recognizing these areas of potential, it is also important to note that Facebook, by itself, cannot have a strong positive impact on the storytelling dynamics of a community that affect civic engagement. Rather, as one of several possible linkages within a community, Facebook's potential for civic engagement 
depends upon the degree to which the site contributes to the strengthening or weakening of a communication infrastructure.

This research was distinct from much of the past communication research exploring the relationship between media use and civic engagement because it was situated within an explanatory and predictive theoretical framework. Understanding the relationship between connection to neighborhood storytelling and civic engagement while also being able to predict the impact of changes in feelings of neighborhood belonging, collective efficacy, or civic participation holds tremendous potential for strategic efforts to increase civic engagement. By providing preliminary insight into how one social networking site fits into communities' communication infrastructures to facilitate civic engagement, this research extended CIT and provided new insight into the role that Facebook might play in such strategic endeavors. Equipped with a preliminary understanding of Facebook's potential, it will be important for citizens, communities, and researchers to capitalize on strengths and strategically build upon current ways of engaging to improve social capital and increase civic engagement. 


\section{References}

Adler, R. P., Goggin, J. (2005). What do we mean by “civic engagement"? Journal of Transformative Education, 3(3), 236-253.

Babbie, E. R. (2007). The basics of social research (4 ${ }^{\text {th }}$, ed.). Boston, MA: Wadsworth.

Bakker, T. P., \& de Vreese, C. H. (2011). Good news for the future? Young people, internet use, and political participation. Communication Research, 38(4), 451470.

Ball-Rokeach, S. J., Kim, Y.-C., \& Matei, S. (2001). Storytelling neighborhood: Paths to belonging in diverse urban environments. Communication Research, 28, 392-428.

Beaudoin, C. E. (2009). Exploring the association between news use and social capital: Evidence of variance by ethnicity and medium. Communication Research, 36(5), $611-636$.

Beaudoin, C. E., \& Thorson, E. (2006). The social capital of Blacks and Whites: Differing effects of the mass media in the United States. Human Communication Research, 32, 157-177.

Bennett, W.L. (2008). Changing citizenship in the digital age. In W.L. Bennett (Ed.), Civic life online (pp. 1-24). Cambridge, MA: The MIT Press.

Bimber, B. (1999). The internet and citizen communication with government: Does the medium matter? Political Communication, 16(4), 409-428.

Bimber, B. (2000). The study of information technology and civic engagement. Political Communication, 17(4), 329-333. 
Boulianne, S. (2009). Does internet use affect engagement? A meta-analysis of research. Political Communication, 26, 193-211.

Bourdieu, P. (1986). Forms of capital. In J.G. Richardson (Ed.), Handbook of theory and research for the sociology of education (pp.241-258). New York: Greenwood Press.

boyd, d. m., \& Ellison, N. (2007). Social network sites: Definition, history, and scholarship. Journal of Computer Mediated Communication, 13, 210-230.

Brady, H. E., Verba, S., \& Schlozman, K. L. (1995). Beyond SES: A resource model of political participation, The American Political Science Review, 89(2), 271-294.

Brammer, C. \& Parker, R. (2007). Samford University's communication studies: Seizing an opportunity. In K. Kecskes (Ed.) Engaging departments: Moving faculty culture from private to public, individual to collective focus for the common good. (pp. 63-75). San Francisco, CA: Anker Publishing Company, Inc.

Coleman, J. S. (1990). Foundations of social theory. Massachusetts: The Belknap Press and Harvard University Press.

Coleman, R., Lieber, P., Mendelson, A. L., \& Kurpius, D. D. (2008). Public life and the internet: If you build a better website, will citizens become engaged? New Media \& Society, 10(2), 179-201.

Cornfield, M. (2000). The internet and democratic participation. National Civic Review, $89(3), 235-241$.

Delli Carpini, M. X. (2000). Gen.com: Youth, civic engagement, and the new information environment. Political Communication, 17, 341-349. 
Duggan, M., \& Brenner, J. (2013). The demographics of social media users-2012. Retrieved October 6, 2013 from http://pewinternet.org/ /media//Files/Reports/2013/PIP_SocialMediaUsers.pdf

Earl, J., \& Schussman, A. (2008). Contesting cultural control: Youth culture and online petitioning. In W.L. Bennett (Ed.), Civic life online (pp. 71-95). Cambridge, MA: The MIT Press.

Ellison, N. B., Steinfield, C., \& Lampe, C. (2007). The benefits of Facebook "friends:" Social capital and college students use of online social network sites. Journal of Computer-Mediated Communication, 12, 1143-1168.

Enda, J., \& Mitchell, A. (2013). Friends and family - Important drivers of news. The State of The News Media 2013. Retrieved August 10, 2013 from http://stateofthemedia.org/2013/special-reports-landing-page/friends-and-familyimportant-drivers-of-news/

Gil de Zuniga, H., Jung, N., Valenzuela, S. (2012). Social media use for news and individuals' social capital, civic engagement, and political participation. Journal of Computer-Mediated Communication, 17, 319-336.

Gladwell, M. (2010, October). Small change: Why the revolution will not be tweeted. The New Yorker. Retrieved January 24, 2014 from http://www.newyorker.com/reporting/2010/10/04/101004fa_fact_gladwell?curren tPage $=$ all

Goldfarb, C. B. (2011). How changes in the economics of broadcast television are affecting news and sports programming and the policy goals of localism, diversity 
of voices, and competition. Journal of Current Issues in Media and Telecommunications, 3(2), 111-144.

Habermas, J. (1984). The theory of communicative action. (T. McCarthy, Trans.). Boston, MA: Beacon Press.

Hardy, B. W., \& Scheufele, D. A. (2005). Examining differential gains from internet use: Comparing the moderating role of talk and online interactions. Journal of Communication, 55(1), 71-84.

Huntemann, N. (1999). Corporate interference: The commercialization and concentration of radio post the 1996 Telecommunications Act. Journal of Communication Inquiry, 23, 390-407.

Jeffres, L. W., Lee, J.-W., Neuendorf, K., \& Atkin, D. (2007). Newspaper reading supports community involvement. Newspaper Research Journal, 28(1), 6-23.

Jeffres, L. W. (2002). Urban communication systems: Neighborhoods and the search for community. Cresskill, NJ: Hampton Press, Inc.

Jenkins, H. (2006). Convergence culture: Where old and new media collide. New York, NY: New York University Press.

Jennings, M. K., \& Zeitner, V. (2003). Internet use and civic engagement: A longitudinal analysis, Public Opinion Quarterly, 67(3), 311-334.

Kim, Y., Hsu, S.-H., \& Gil de Zuniga, H. (2013). Influence of social media use on discussion network heterogeneity and civic engagement: The moderating role of personality traits. Journal of Communication, 63, 498-516. 
Kim, Y.-C., \& Ball-Rokeach, S. J. (2006a). Civic engagement from a communication infrastructure perspective. Communication Theory, 16, 173-197.

Kim, Y.-C., \& Ball-Rokeach, S.J. (2006b). Community storytelling network, neighborhood context, and civic engagement: A multilevel approach. Human Communication Research, 32, 411-439.

Kirchhoff, S. (2011). The U.S. newspaper industry in transition. Journal of Current Issues in Media and Telecommunications, 2(1), 27-51.

Matei, S., \& Ball-Rokeach, S. (2003). The internet in the communication infrastructure of urban residential communities: Macro- or mesolinkage? Journal of Communication, 53(4), 642-657.

McCarthy, T., \& Zald, M. N. (1977). Resource mobilization and social movements: A partial theory. American Journal of Sociology, 82, 1212-1241.

McLeod, J. M., Scheufele, D. A., \& Moy, P. (1999). Community, communication, and participation: The role of mass media and interpersonal discussion in local political participation. Political Communication, 16, 315-336.

Moon, J. W., \& Kim, Y. G. (2001). Extending the TAM for a World-Wide-Web context. Information \& Management, 38, 217-230.

Morozov, E. (2009, September). From slacktivism to activism. Foreign Policy. Retrieved April 8, 2014 from http://neteffect.foreignpolicy.com/posts/2009/09/05/from_slacktivism_to_activis $\mathrm{m}$ 
Moy, P., Manosevitch, E., Stamm, K., \& Dunsmore, K. (2005). Linking dimensions of internet use and civic engagement. Journalism \& Mass Media Quarterly, 82, 571586.

Nabi, R. L., \& Krcmar, M. (2004). Conceptualizing media enjoyment as attitude: Implications for mass media effects research. Communication Theory, 14(4), 288310.

Nash, J., \& Hoffman, L. H. (2009). Explaining the gap: The interaction of gender and news enjoyment in predicting political knowledge. Communication Research Reports, 26(2), 114-122.

Norris, P. (2001). Digital divide: Civic engagement, information poverty, and the internet world-wide. New York: Cambridge University Press.

Pasek, J., more, e., \& Romer, D. (2009). Realizing the social internet? Online social networking meets offline civic engagement. Journal of Information Technology \& Politics, 6, 197-215.

Pew Research Journalism Project. (2010). How news happens: A study of the news ecosystem of one American city. Retrieved December 16, 2013 from http://www.journalism.org/2010/01/11/how-news-happens/

Putnam, R. D. (1995). Bowling alone: America's declining social capital. Journal of Democracy, 6(1), 65-78.

Putnam, R. D. (2000). Bowling alone: The collapse and revival of American community. New York, NY: Harper Collins. 
Putnam, R. D. \& Goss, K. A. (2002). Introduction. In R.D. Putnam (Ed.), Democracies in flux (pp. 3-19). New York: Oxford University Press.

Raynes-Goldie, K. \& Walker, L. (2008). Our space: Online civic engagement tools for youth. In W.L. Bennett (Ed.), Civic life online (pp. 161-188). Cambridge, MA: The MIT Press.

Rohe, W. M. (2004). Building social capital through community development. Journal of the American Planning Association, 70, 158-164.

Rubin, A. M. (1993). Audience activity and media use. Communication Monographs, 60(1), 98-105.

Scheufele, D. A. (2002). Examining differential gains from mass media and their implications for participatory behavior. Communication Research, 29(1), 46-65.

Scheufele, D. A., \& Nisbet, M. C. (2002). Being a citizen online: New opportunities and dead ends. Harvard International Journal of Press/Politics, 7(3). 55-75.

Scheufele, D. A., \& Shah, D. V. (2000). Personality strength and social capital: The role of dispositional and informational variables in the production of civic participation. Communication Research, 27(2), 107-131.

Schoenfeld, D. A. (2010). Statistical considerations for clinical trials and scientific experiments. Retrieved from http://hedwig.mgh.harvard.edu/sample_size/size.html

Shah, D. V., Cho, J., Eveland, W. P., Jr., \& Kwak, N. (2005). Information and expression in a digital age: Modeling internet effects on civic participation. Communication Research, 32(5), 531-565. 
Shah, D. V., Kwak, N., \& Holbert, R. L. (2001). "Connecting” and "disconnecting” with civic life: Patterns of internet use and the production of social capital. Political Communication, 18(2), 141-162.

Shah, D. V., McLeod, J. M., \& Yoon, S. H. (2001). Communication, context, and community: An exploration of print, broadcast, and internet influences. Communication Research, 28(4), 464-506.

Smith, A. (2013). Civic engagement in the digital age. Pew Research Center's Internet \& American Life Project. Retrieved June 7, 2014 from http://www.pewinternet.org/2013/04/25/civic-engagement-in-the-digital-age/

Smock, A. D., Ellison, N. B., Lampe, C., \& Wohn, D. Y. (2011). Facebook as a toolkit: A uses and gratification approach to unbundling feature use. Computers in Human Behavior, 27, 2322-2329.

Sparks, G. (2012). Uses and gratifications of Elihu Katz. In E.Griffin (Ed.), A first look at communication theory (pp. 257-265). New York, NY: McGraw-Hill.

Stamm, K. R. (1985). Newspaper use and community ties: Toward a dynamic theory. Norwood, NJ: Ablex Publishing Corporation.

de Tocqueville, A. (1845/2010). Democracy in America (Vol. 2). Charleston, SC: Nabu Press.

Verba, S., Schlozman, K. L., Brady, H.E. (1995). Voice and equality: Civic volunteerism in American politics. Cambridge, MA: Harvard University Press.

Wells, C. (2010). Citizenship and communication in online youth civic engagement projects. Information, Communication, \& Society, 13(3), 419-441. 
Wilkin, H. A., Moran, M. B., Ball-Rokeach, S. J., Kim, Y.-C. (2010). Applications of communication infrastructure theory. Health Communication, 25, 611-612.

Williams, F., \& Monge, P. (2001). Reasoning with statistics: How to read quantitative research. Boston, MA: Wadsworth.

Woolcock, M., \& Narayan, D. (2000). Social capital: Implications for development theory, research, and policy. The World Bank Research Observer, 15(2), 225-249.

Zhang, W., \& Seltzer, T. (2010). Another piece of the puzzle: Advancing social capital theory by examining the effect of political party relationship quality on political and civic participation. International Journal of Strategic Communication, 4, 155170. 


\section{APPENDIX A: RECRUITMENT LETTER}

My name is Sarah Martin, and I am a graduate student at Portland State University. I am beginning a study to learn about how people feel about and get involved with their local communities and I would like to invite you to participate.

Participants in this study should be 18 years of age or older, currently live in the United States, and have a Facebook account. If you choose to participate in this study, you will be asked to complete an online survey that should take approximately 15 minutes.

There are minimal risks associated with participating, as you may feel uncomfortable sharing some information about your feelings about and involvement with your local community. Overall the risks associated with this study are less than one would experience in everyday life. You may not receive any direct intellectual benefit from taking part in this study, but this research may help to increase knowledge that may help others in the future.

In exchange for your participation, you will receive $\$ 0.50$. Participation is completely voluntary and your responses will remain confidential. Your decision to participate or not will not affect your relationship with the researcher or with Portland State University in any way. You may refuse to answer any question on the survey and you may withdraw from the study at any time by simply closing the survey window.

When the survey is complete, you will be asked to enter a survey completion code into Mechanical Turk. Compensation will be handled entirely by Mechanical Turk. The researcher will not have access to your personal information and Mechanical Turk will not have access to your survey responses. As such, your personal information will not be associated with your survey responses. Any information that could possibly be linked to you or identify you will be kept confidential.

If you would like to participate in this study, please click on the survey link provided. You can take this survey on any device with internet access. If you have any questions or concerns about your participation in this study, please contact the researcher, Sarah Martin, at samart2@pdx.edu. If you have any concerns about your rights as a research subject, please contact Research and Strategic Partnerships, Market Center Building $6^{\text {th }}$ floor, Portland State University, (503)725-4288.

Thank you for your time. Your participation is greatly appreciated.

Sincerely,

Sarah Martin

Graduate Student

Portland State University 


\section{APPENDIX B: INFORMED CONSENT}

You are invited to participate in a research study conducted by Sarah Martin under the direction of Dr. Frank. This study attempts to collect information about how people feel about and get involved with their local communities. To be eligible to participate in this study you must be 18 years of age or older, currently live in the United States, have a Facebook account, and have actively used your Facebook account at least three times during the past week.

\section{Procedures}

If you decide to participate, you will be asked to complete the following questionnaire. The questionnaire will take approximately 15 minutes or less.

\section{$\underline{\text { Risks/Discomforts }}$}

Risks are minimal for involvement in this study. However, you may feel uncomfortable when asked to share information about your feelings about and involvement with your local community. You are welcome to skip any question that you feel uncomfortable answering.

\section{Benefits}

You may not receive any direct benefit from taking part in this study. However, it is hoped that through your participation, the study may help to increase knowledge which may help others in the future.

\section{Confidentiality}

All information that is obtained in connection with this study will be kept confidential and will only be reported in an aggregate format (by reporting only combined results and never reporting individual ones). All questionnaires will be concealed, and no one other than the research team will have access to them. At no point will your name be linked to your answers.

\section{Compensation}

You will be paid $\$ 0.50$ for your participation. Follow the directions at the end of the survey to enter the completion code into your Mechanical Turk account. Your personal information will not be linked to your survey responses. Mechanical Turk, the third party from whom you will receive compensation, will not have access to your survey responses and the research team will not have access to the personal information used to coordinate compensation. 


\section{$\underline{\text { Participation }}$}

Participation in this research study is completely voluntary. You have the right to withdraw at any time or refuse to participate entirely, and it will not affect your relationship with the research team or Portland State University in any way.

\section{Questions about the Research}

If you have questions or concerns regarding this study, contact Sarah Martin at samart2@pdx.edu or Dr. Frank at1frank@pdx.edu.

\section{Questions about your Rights as Research Participants}

If you have questions or concerns about your rights as a research subject, please contact the Portland State University Office of Research Integrity, 1600 SW 4th Avenue, Market Center Building, Suite 620, Portland, OR 97207; phone (503)725-2227 or 1(877)4804400 .

By completing this survey, you are certifying that you are 18 years of age or older, that you have read and understand the above information and agree to take part in the survey. Press the "Print" button below to keep a copy of this form for your own records.

If at this point you choose to continue in this research study, please click "Next" to continue. 


\section{APPENDIX C: SURVEY INSTRUMENT}

\section{Inclusion Criteria}

Do you have a Facebook account?

O Yes

No

Have you actively used Facebook at least 3 times during the past week?

$\mathrm{O}$ Yes

O No

Please think about your experience using Facebook.

\section{Facebook Intensity}

Please indicate how much you agree or disagree with each of the following statements.

\begin{tabular}{|c|c|c|c|c|c|}
\hline & $\begin{array}{l}\text { Strongly } \\
\text { disagree }\end{array}$ & Disagree & $\begin{array}{c}\text { Neither } \\
\text { agree } \\
\text { nor } \\
\text { disagree }\end{array}$ & Agree & $\begin{array}{l}\text { Strongly } \\
\text { agree }\end{array}$ \\
\hline $\begin{array}{l}\text { Facebook is part of my } \\
\text { everyday activity. }\end{array}$ & 0 & 0 & $\bigcirc$ & 0 & 0 \\
\hline $\begin{array}{l}\text { I am proud to tell people I am } \\
\text { on Facebook. }\end{array}$ & 0 & $O$ & 0 & 0 & 0 \\
\hline $\begin{array}{l}\text { Facebook has become part of } \\
\text { my daily routine. }\end{array}$ & 0 & 0 & 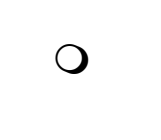 & 0 & 0 \\
\hline $\begin{array}{l}\text { I feel out of touch when I } \\
\text { haven't logged onto my } \\
\text { Facebook for a while. }\end{array}$ & 0 & 0 & 0 & 0 & 0 \\
\hline $\begin{array}{l}\text { I feel I am part of the } \\
\text { Facebook community. }\end{array}$ & 0 & 0 & 0 & 0 & 0 \\
\hline $\begin{array}{l}\text { I would be sorry if Facebook } \\
\text { shut down. }\end{array}$ & 0 & 0 & 0 & 0 & 0 \\
\hline
\end{tabular}

Approximately how many TOTAL Facebook friends do you have?

Of that total, approximately how many of your Facebook friends live in your local community? 
In the past week, on average, approximately how much time PER DAY have you spent actively using Facebook?
O 0 -14 minutes
O 15-29 minutes
O 30-59 minutes
O 1 hour or more

\section{Enjoyment of Using Facebook}

Please indicate how much you agree or disagree with each of the following statements.

\begin{tabular}{|c|c|c|c|c|c|}
\hline & $\begin{array}{l}\text { Strongly } \\
\text { disagree }\end{array}$ & Disagree & $\begin{array}{l}\text { Neither } \\
\text { agree } \\
\text { nor } \\
\text { disagree }\end{array}$ & Agree & $\begin{array}{l}\text { Strongly } \\
\text { agree }\end{array}$ \\
\hline $\begin{array}{l}\text { Using Facebook provides me } \\
\text { with a lot of enjoyment. }\end{array}$ & O & $\mathrm{O}$ & $\mathrm{O}$ & $\mathrm{O}$ & $\mathrm{O}$ \\
\hline I have fun using Facebook. & O & O & O & O & O \\
\hline Using Facebook bores me. & $\mathrm{O}$ & 0 & O & 0 & 0 \\
\hline
\end{tabular}

\section{Facebook Use for News}

How often do you use Facebook to...

\begin{tabular}{|c|c|c|c|c|c|c|c|c|c|c|}
\hline & $\begin{array}{c}\text { Never } \\
1\end{array}$ & 2 & 3 & 4 & 5 & 6 & 7 & 8 & 9 & $\begin{array}{l}\text { All } \\
\text { the } \\
\text { time } \\
10\end{array}$ \\
\hline $\begin{array}{l}\text { Stay informed about } \\
\text { current events and } \\
\text { public affairs? }\end{array}$ & $\bigcirc$ & 0 & 0 & 0 & 0 & 0 & 0 & 0 & 0 & 0 \\
\hline $\begin{array}{l}\text { Stay informed about } \\
\text { the local community? }\end{array}$ & 0 & 0 & 0 & 0 & 0 & 0 & 0 & 0 & 0 & 0 \\
\hline $\begin{array}{l}\text { Get news about } \\
\text { current events from } \\
\text { news media? }\end{array}$ & 0 & 0 & 0 & 0 & 0 & 0 & $\bigcirc$ & 0 & 0 & 0 \\
\hline $\begin{array}{l}\text { Get news about } \\
\text { current events } \\
\text { through friends? }\end{array}$ & 0 & 0 & 0 & 0 & 0 & 0 & 0 & 0 & 0 & 0 \\
\hline
\end{tabular}




\section{Uses and Gratifications of Facebook}

Please indicate how much you agree or disagree with each of the following statements. I use Facebook...

\begin{tabular}{|c|c|c|c|c|c|}
\hline & $\begin{array}{l}\text { Strongly } \\
\text { disagree }\end{array}$ & Disagree & $\begin{array}{l}\text { Neither } \\
\text { agree nor } \\
\text { disagree }\end{array}$ & Agree & $\begin{array}{l}\text { Strongly } \\
\text { agree }\end{array}$ \\
\hline Because it's enjoyable. & 0 & O & O & 0 & 0 \\
\hline Because it's entertaining. & $\mathrm{O}$ & $\mathrm{O}$ & O & $\mathrm{O}$ & O \\
\hline Because it relaxes me. & O & $\mathrm{O}$ & $\mathrm{O}$ & O & $\mathrm{O}$ \\
\hline $\begin{array}{l}\text { Because it allows me to } \\
\text { unwind. }\end{array}$ & $\mathrm{O}$ & $\mathrm{O}$ & $\mathrm{O}$ & $\mathrm{O}$ & $\mathrm{O}$ \\
\hline Because it's a pleasant rest. & $\mathrm{O}$ & $\mathrm{O}$ & $\mathrm{O}$ & O & $\mathrm{O}$ \\
\hline To provide information. & $\mathrm{O}$ & $\mathrm{O}$ & $\mathrm{O}$ & $\mathrm{O}$ & $\mathrm{O}$ \\
\hline $\begin{array}{l}\text { To present information } \\
\text { about a special interest of } \\
\text { mine. }\end{array}$ & $\mathrm{O}$ & $\mathrm{O}$ & $\mathrm{O}$ & $\mathrm{O}$ & $\mathrm{O}$ \\
\hline $\begin{array}{l}\text { To share information that } \\
\text { may be of use or interest to } \\
\text { others. }\end{array}$ & $\mathrm{O}$ & $\mathrm{O}$ & O & $\mathrm{O}$ & $\mathrm{O}$ \\
\hline $\begin{array}{l}\text { To provide personal } \\
\text { information about myself. }\end{array}$ & $\mathrm{O}$ & $\mathrm{O}$ & $\mathrm{O}$ & $\mathrm{O}$ & $\mathrm{O}$ \\
\hline $\begin{array}{l}\text { To tell others a little bit } \\
\text { about myself. }\end{array}$ & $\mathrm{O}$ & $\mathrm{O}$ & $\mathrm{O}$ & $\mathrm{O}$ & $\mathrm{O}$ \\
\hline $\begin{array}{l}\text { So I can forget about } \\
\text { school, work, or other } \\
\text { things. }\end{array}$ & $\mathrm{O}$ & $\mathrm{O}$ & $\mathrm{O}$ & $\mathrm{O}$ & O \\
\hline $\begin{array}{l}\text { So I can get away from the } \\
\text { rest of my family or others. }\end{array}$ & O & $\mathrm{O}$ & $\mathrm{O}$ & $\mathrm{O}$ & $\mathrm{O}$ \\
\hline $\begin{array}{l}\text { So I can get away from } \\
\text { what I'm doing. }\end{array}$ & $\mathrm{O}$ & $\mathrm{O}$ & $\mathrm{O}$ & $\mathrm{O}$ & $\mathrm{O}$ \\
\hline $\begin{array}{l}\text { Because everybody else is } \\
\text { doing it. }\end{array}$ & $\mathrm{O}$ & $\mathrm{O}$ & $\mathrm{O}$ & $\mathrm{O}$ & $\mathrm{O}$ \\
\hline Because it's the thing to do. & O & $\mathrm{O}$ & O & $\mathrm{O}$ & $\mathrm{O}$ \\
\hline Because it's cool. & O & $\mathrm{O}$ & $\mathrm{O}$ & $\mathrm{O}$ & O \\
\hline So I won't have to be alone. & $\mathrm{O}$ & $\mathrm{O}$ & $\mathrm{O}$ & O & O \\
\hline $\begin{array}{l}\text { When there's no one else to } \\
\text { talk or be with. }\end{array}$ & $\mathrm{O}$ & $\mathrm{O}$ & $\mathrm{O}$ & $\mathrm{O}$ & $\mathrm{O}$ \\
\hline Because it makes me feel & O & O & $\mathrm{O}$ & $\mathrm{O}$ & $\mathrm{O}$ \\
\hline
\end{tabular}




\begin{tabular}{|c|c|c|c|c|c|}
\hline less lonely. & & & & & \\
\hline $\begin{array}{l}\text { Because it's helpful for my } \\
\text { professional future. }\end{array}$ & $\mathrm{O}$ & $\mathrm{O}$ & $\mathrm{O}$ & $\mathrm{O}$ & O \\
\hline $\begin{array}{l}\text { To post my resume and/or } \\
\text { other work online. }\end{array}$ & $\mathrm{O}$ & O & $\mathrm{O}$ & $\mathrm{O}$ & O \\
\hline $\begin{array}{l}\text { To help me network with } \\
\text { professional contacts. }\end{array}$ & $\mathrm{O}$ & $\mathrm{O}$ & $\mathrm{O}$ & $\mathrm{O}$ & $\mathrm{O}$ \\
\hline $\begin{array}{l}\text { To keep in touch with } \\
\text { friends and family. }\end{array}$ & $\mathrm{O}$ & $\bigcirc$ & 0 & 0 & 0 \\
\hline $\begin{array}{l}\text { To communicate with } \\
\text { distant friends. }\end{array}$ & $\bigcirc$ & 0 & 0 & 0 & 0 \\
\hline $\begin{array}{l}\text { To communicate with } \\
\text { friends who live nearby. }\end{array}$ & 0 & 0 & 0 & 0 & 0 \\
\hline $\begin{array}{l}\text { Because I just like to play } \\
\text { around on Facebook. }\end{array}$ & $\mathrm{O}$ & O & 0 & O & O \\
\hline $\begin{array}{l}\text { Because it's a habit, just } \\
\text { something to do. }\end{array}$ & $\mathrm{O}$ & 0 & 0 & 0 & $\mathrm{O}$ \\
\hline $\begin{array}{l}\text { When I have nothing better } \\
\text { to do. }\end{array}$ & 0 & 0 & 0 & 0 & $\mathrm{O}$ \\
\hline $\begin{array}{l}\text { Because it passes the time } \\
\text { away, particularly when I'm } \\
\text { bored. }\end{array}$ & 0 & 0 & $\bigcirc$ & 0 & 0 \\
\hline $\begin{array}{l}\text { Because it gives me } \\
\text { something to do to occupy } \\
\text { my time. }\end{array}$ & $\mathrm{O}$ & $\mathrm{O}$ & $\mathrm{O}$ & $\mathrm{O}$ & $\mathrm{O}$ \\
\hline To meet new people. & $\mathrm{O}$ & $\mathrm{O}$ & O & $\mathrm{O}$ & O \\
\hline
\end{tabular}


Scope of Connection to Micro-Level Storytelling on Facebook

Thinking about your activities on Facebook, how often...

\begin{tabular}{|c|c|c|c|c|c|c|c|c|c|c|}
\hline & \multicolumn{8}{|c|}{ Never } & \multicolumn{2}{|c|}{$\begin{array}{l}\text { All the } \\
\text { time }\end{array}$} \\
\hline & 1 & 2 & 3 & 4 & 5 & 6 & 7 & 8 & 9 & 10 \\
\hline $\begin{array}{l}\text { Do you mention things happening } \\
\text { in your neighborhood in a status } \\
\text { update? }\end{array}$ & 0 & 0 & 0 & 0 & 0 & 0 & 0 & 0 & O & 0 \\
\hline $\begin{array}{l}\text { Do you read friends' status updates } \\
\text { about things happening in your } \\
\text { neighborhood? }\end{array}$ & 0 & 0 & 0 & 0 & 0 & 0 & 0 & 0 & 0 & 0 \\
\hline $\begin{array}{l}\text { Do you comment on friends' status } \\
\text { updates about things happening in } \\
\text { your neighborhood? }\end{array}$ & 0 & 0 & 0 & O & 0 & 0 & 0 & 0 & 0 & 0 \\
\hline $\begin{array}{l}\text { Do you "like" friends' status } \\
\text { updates about things happening in } \\
\text { your neighborhood? }\end{array}$ & 0 & 0 & O & 0 & 0 & 0 & 0 & 0 & 0 & 0 \\
\hline $\begin{array}{l}\text { Do you write posts on friends' } \\
\text { timelines about things happening in } \\
\text { your neighborhood? }\end{array}$ & 0 & 0 & 0 & 0 & 0 & 0 & 0 & 0 & 0 & 0 \\
\hline
\end{tabular}

\section{Connection to Community Organizations on Facebook}

The following questions ask whether you use Facebook to connect with groups and organizations from your local community. You might connect by joining Facebook groups or "liking" Facebook pages associated with local groups and organizations. Thinking about these different ways of connecting, are you connected with any of the following on Facebook...

\begin{tabular}{|l|c|c|}
\hline $\begin{array}{l}\text { Sport or recreational } \\
\text { organizations or clubs? }\end{array}$ & Yes & No \\
$\begin{array}{l}\text { Neighborhood groups or } \\
\text { homeowners' associations? }\end{array}$ & 0 & 0 \\
$\begin{array}{l}\text { Political or educational } \\
\text { organizations? }\end{array}$ & 0 & 0 \\
$\begin{array}{l}\text { Cultural, ethnic, or religious } \\
\text { organizations or groups? }\end{array}$ & 0 & 0 \\
Other organizations or groups? & 0 & 0 \\
\hline
\end{tabular}




\section{Connection to Local Media on Facebook}

Thinking about your activities on Facebook during the past week, have you...

\begin{tabular}{l|l|}
\hline $\begin{array}{l}\text { Shared any stories from newspapers produced } \\
\text { for your area or for your ethnic group? }\end{array}$ & Yes \\
$\begin{array}{l}\text { Read any stories from newspapers produced } \\
\text { for your area or for your ethnic group? }\end{array}$ & 0 \\
$\begin{array}{l}\text { Shared any video clips from television and } \\
\text { cable channels that target your area or are } \\
\text { produced for your ethnic group? }\end{array}$ & 0 \\
$\begin{array}{l}\text { Watched any video clips from television and } \\
\text { cable channels that target your area or are } \\
\text { produced for your ethnic group? }\end{array}$ & \\
$\begin{array}{l}\text { Shared any sound clips from radio stations } \\
\text { that target your area or are produced for your } \\
\text { ethnic group? }\end{array}$ & \\
$\begin{array}{l}\text { Listened to any sound clips from radio } \\
\text { stations that target your area or are produced } \\
\text { for your ethnic group? }\end{array}$ & 0 \\
\hline
\end{tabular}

\section{Neighborhood belonging}

The following questions ask about your relationship with your neighbors. Please indicate your level of agreement with each of the following statements.

\begin{tabular}{|c|c|c|c|c|c|}
\hline & $\begin{array}{l}\text { Strongly } \\
\text { disagree }\end{array}$ & Disagree & $\begin{array}{l}\text { Neither } \\
\text { agree nor } \\
\text { disagree }\end{array}$ & Agree & $\begin{array}{c}\text { Strongly } \\
\text { agree }\end{array}$ \\
\hline $\begin{array}{l}\text { You are interested in } \\
\text { knowing what your } \\
\text { neighbors are like. }\end{array}$ & 0 & 0 & 0 & 0 & 0 \\
\hline $\begin{array}{l}\text { You enjoy meeting and } \\
\text { talking with your } \\
\text { neighbors. }\end{array}$ & 0 & 0 & 0 & 0 & 0 \\
\hline $\begin{array}{l}\text { It's easy to become } \\
\text { friends with your } \\
\text { neighbors. }\end{array}$ & 0 & 0 & 0 & 0 & 0 \\
\hline $\begin{array}{l}\text { Your neighbors always } \\
\text { borrow things from you } \\
\text { and your family. }\end{array}$ & 0 & 0 & 0 & 0 & 0 \\
\hline
\end{tabular}


How many of your neighbors do you know well enough to do the following?

\begin{tabular}{|l|c|c|c|c|c|c|}
\hline & 0 & 1 & 2 & 3 & 4 & 5 or \\
more
\end{tabular}

\section{Collective Efficacy}

How many of your neighbors do you feel could be counted on to do something if:

\begin{tabular}{|c|c|c|c|c|c|}
\hline & None & Few & Some & Most & All \\
\hline $\begin{array}{l}\text { The sports field or park that } \\
\text { neighborhood kids want to play on } \\
\text { has become unsafe due to poor } \\
\text { maintenance or gangs, for example? }\end{array}$ & 0 & 0 & 0 & 0 & 0 \\
\hline $\begin{array}{l}\text { You asked them to help you organize } \\
\text { a holiday block party? }\end{array}$ & 0 & 0 & 0 & 0 & 0 \\
\hline $\begin{array}{l}\text { There were dangerous potholes on the } \\
\text { streets where you live? }\end{array}$ & 0 & 0 & 0 & 0 & 0 \\
\hline $\begin{array}{l}\text { A stop sign or speed bump was } \\
\text { needed to prevent people from driving } \\
\text { too fast through your neighborhood? }\end{array}$ & 0 & 0 & 0 & 0 & 0 \\
\hline $\begin{array}{l}\text { The trees along the streets were } \\
\text { uprooting the sidewalks making them } \\
\text { unsafe? }\end{array}$ & 0 & 0 & 0 & 0 & 0 \\
\hline $\begin{array}{l}\text { A child in your neighborhood is } \\
\text { showing clear evidence of being in } \\
\text { trouble, or getting into big trouble? }\end{array}$ & 0 & 0 & 0 & 0 & 0 \\
\hline
\end{tabular}

\section{Overall Scope of Connection to Micro-Level Storytelling}

How often do you have discussions with other people about things happening in your neighborhood?

\begin{tabular}{|c|c|c|c|c|c|c|c|c|c|}
\hline $\begin{array}{c}\text { Never } \\
1\end{array}$ & 2 & 3 & 4 & 5 & 6 & 7 & 8 & 9 & $\begin{array}{c}\text { All } \\
\text { the } \\
\text { time } \\
10\end{array}$ \\
\hline 0 & 0 & 0 & 0 & 0 & 0 & 0 & 0 & 0 & 0 \\
\hline
\end{tabular}




\section{Connection to Community Organizations}

Do you or someone in your household participate in...

\begin{tabular}{|l|c|c|}
\hline $\begin{array}{l}\text { Sport or recreational } \\
\text { organizations or clubs? }\end{array}$ & Nes, do participate & 0 \\
$\begin{array}{l}\text { Neighborhood groups or } \\
\text { homeowners' associations? }\end{array}$ & 0 & 0 \\
$\begin{array}{l}\text { Political or educational } \\
\text { organizations? }\end{array}$ & 0 & 0 \\
$\begin{array}{l}\text { Cultural, ethnic, or religious } \\
\text { organizations or groups? }\end{array}$ & 0 & 0 \\
Other organizations or groups? & 0 & 0 \\
\hline
\end{tabular}

Approximately how often do you attend a religious service?
O Never
Less than once a month
At least once a month
At least every few weeks
At least once a week
O More than once a week

\section{Connection to Local Media}

Approximately how many hours did you spend last week reading newspapers produced for your area or for your ethnic group?

O None

A few minutes to less than 1 hour

O 1 hour to less than 2 hours

O 2 hours to less than 3 hours

O 3 hours to less than 4 hours

O 5 hours or more

Approximately how many hours did you spend last week watching television and cable channels that target your area or are produced for your ethnic group?

None

A few minutes to less than 1 hour

O 1 hour to less than 2 hours

O 2 hours to less than 3 hours

O 3 hours to less than 4 hours

O 5 hours or more 
Approximately how many hours did you spend last week listening to radio stations that target your area or are produced for your ethnic group?

O None

A few minutes to less than 1 hour

O 1 hour to less than 2 hours

O 2 hours to less than 3 hours

O 3 hours to less than 4 hours

O 5 hours or more

\section{Civic Participation}

Since moving to your current neighborhood, have you...

\begin{tabular}{|c|c|c|}
\hline & Yes & No \\
\hline $\begin{array}{l}\text { Attended a city council meeting, public hearing, } \\
\text { or neighborhood council meeting? }\end{array}$ & O & O \\
\hline $\begin{array}{l}\text { Written a letter to the editor of a newspaper, } \\
\text { television station, or magazine? }\end{array}$ & O & O \\
\hline Contacted an elected official about a problem? & O & O \\
\hline Circulated a petition offline? & O & $\bigcirc$ \\
\hline Circulated a petition on Facebook? & $\mathrm{O}$ & O \\
\hline $\begin{array}{l}\text { Taken part in any political demonstration or } \\
\text { protest offline? }\end{array}$ & O & ○ \\
\hline $\begin{array}{l}\text { Taken part in any political demonstration or } \\
\text { protest on Facebook? }\end{array}$ & ○ & ○ \\
\hline
\end{tabular}

\section{Demographics}

For statistical purposes, please share some general information about yourself. All information will remain confidential.

What is your gender?

O Male

O Female

Other

What year were you born?

What is your race?
O White/Caucasian
O African American
O Hispanic
O Asian
O Native American
O Pacific Islander
Other 
How many years have you lived in your neighborhood?

Do you own your home?

$\mathrm{O}$ Yes

O No

If you had to choose, how would you describe the area where you live?

O A big city

O A small city

A suburb of a big city

A suburb of a small city

A town

O A rural area

O Other

What is your combined annual household income?

under $\$ 20,000$

O $20,000-29,999$

O 30,000-39,999

O $40,000-49,999$

O $50,000-59,999$

O $60,000-69,999$

O 70,000-79,999

O $80,000-89,999$

O 90,000-99,999

O 100,000-109,999

O 110,000-119,999

O $120,000-129,999$

O $130,000-139,999$

O $140,000-149,999$

O $150,000+$

How many people live on this income?

What is the highest level of education you have completed?

$O$ Less than High School

O High School / GED

O Some College

2-year College Degree

4-year College Degree

O Masters Degree

O Doctoral Degree

Professional Degree (JD, MD) 